\title{
Okra (Abelmoschus esculentus) in a refugee context in East Africa: Kitchen gardening helps with mineral provision
}

\author{
Desta Woldetsadik $^{1}$ - Eulogio J. Llorent-Martínez ${ }^{2} \cdot$ Solomie Gebrezgabher $^{3} \cdot$ Mary Njenga $^{4,5} \cdot$ Ruth Mendum $^{6}$. \\ Roxana Castillo-López ${ }^{2} \cdot$ Maria L. Fernández-de Córdova ${ }^{2} \cdot$ Hillette Hailu ${ }^{1}$. Colby T. Evans ${ }^{7} \cdot$ Nelly Madani $^{7}$. \\ Tamlyn P. Mafika ${ }^{7} \cdot$ David E. B. Fleming ${ }^{7}$ (D)
}

Received: 9 September 2021 / Accepted: 23 November 2021

Published online: 21 December 2021

(c) The Author(s) 2021 OPEN

\begin{abstract}
Kitchen gardening is considered a way to reconnect with agriculture and complement the cereal-based relief food offered to refugees in East Africa. This work aimed at profiling mineral content of okra in four refugee camps and settlements located in Ethiopia and Uganda and its contribution to adequate intake (Als) or recommended dietary allowances (RDAs) for young children and pregnant and lactating women (PLW). The study also evaluated the applicability of portable X-ray fluorescence (PXRF) as compared with inductively coupled plasma mass spectrometry (ICP-MS) for mineral profiling of okra powder samples. The contents of minerals $\left(\mathrm{mg} \mathrm{kg}^{-1}\right)$ from the ICP-MS readings were in the following ranges: $\mathrm{K}$ (14,385-33,294), Ca (2610-14,090), P (3178-13,248), Mg (3896-7986), Cu (3.81-19.3), Fe (75.7-1243), Zn (33-141) and $\mathrm{Mn}$ (23.1-261). Regardless of geographic origin, at low-end consumption probability $\left(17 \mathrm{~g} \mathrm{day}^{-1}\right.$ for young children and $68 \mathrm{~g} \mathrm{day}^{-1}$ for PLW), okra could contribute $15 \%$ (2.7-12.9\%) Al for macro-minerals ( $\mathrm{K}$ and $\mathrm{Ca}$ ). In addition, the contributions to RDA values for Fe and $\mathrm{Zn}$, elements of known public health interest, ranged from 4.5 to $34.7 \%$ for young children. Interestingly, regression lines revealed strong agreement between ICP-MS and PXRF readings for Mn and $\mathrm{Zn}$, with $\mathrm{R}^{2}$ values $>0.91$. This information is useful in support of nutrition-sensitive kitchen gardening programs through scaling culturally important crops in refugee settings.
\end{abstract}

Keywords Okra · Minerals · ICP-MS · PXRF · Refugee camps and settlements · East Africa

\section{Introduction}

Conflict driven large scale displacement (both internal and external) is among the main challenges facing sub-Saharan Africa (SSA) today. According to the United Nations
High Commissioner for Refugees (UNHCR) [1], more than 2.3 million South Sudanese uprooted from their homes have fled to neighboring countries (Uganda, Ethiopia and Kenya), with $82 \%$ of them being women or children [2, 3]. These refugees face tremendous social, health, and

Supplementary Information The online version contains supplementary material available at https://doi.org/10.1007/s42452-02104898-6.

David E. B. Fleming, dfleming@mta.ca| ${ }^{1}$ Department of Soil and Water Resources Management, Wollo University, Dessie, Ethiopia. ${ }^{2}$ Department of Physical and Analytical Chemistry, Faculty of Experimental Sciences, University of Jaén, Campus Las Lagunillas, 23071 Jaén, Spain. ${ }^{3}$ International Water Management Institute (IWMI), Cantonments, Accra, Ghana. ${ }^{4}$ World Agroforestry (ICRAF), Nairobi, Kenya. ${ }^{5}$ Wangari Maathai Institute for Peace and Environmental Studies, University of Nairobi, Nairobi, Kenya. ${ }^{6}$ Office of International Programs, College of Agricultural Sciences, Pennsylvania State University, State College, USA. ${ }^{7}$ Physics Department, Mount Allison University, Sackville, NB, Canada.

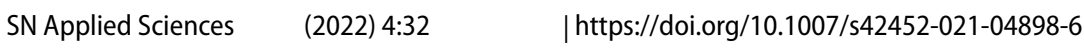


livelihood challenges $[2,4]$. As such, they often become dependent on slow-cooking cereal-based relief foods and experience reduced food diversity and micro-nutrient deficiency including Vitamin $C$ [5-7]. Most recently the Covid 19 pandemic has made delivery of relief foods more difficult.

Micro-nutrients are crucial in various biochemical processes and play a pivotal role in maintaining normal body functions across life stages. Of particular concern in the refugee context in SSA is the low intake of micro-minerals, particularly important for nutritionally vulnerable groups including young children, pregnant and lactating women (PLW) as the main food aid comprise of cereals such as maize [8-10]. According to the World Food Programme of the United Nations (WFP) [11] and Webb et al. [12], the first 1000 days of life may occur in a full-blown humanitarian crisis. Protecting the youngest children as well as PLW from micro-nutrient deficiency is a crucial consideration in institutionally fragile environments. Inadequate intake of certain minerals during pregnancy and lactation, and at an early stage of life have been linked to various health disorders including anemia, preterm delivery, pre-eclampsia, teratogenicity, and embryonic mortality [13-15]. Notably, the micro-nutrient requirements for these groups of women are higher compared to women in other life stages. From a policy perspective, understanding how much specific food crops can contribute to the health of women and children is a vital guide for nutrition security programs.

On the other hand, under-utilized orphan fruits and vegetables may contribute to improving micro-nutrient status and food security in SSA [16, 17]. Fortunately, most of these orphan crops are well adapted to unfavorable environmental conditions (including low soil fertility and water stress) and are reported to grow well in refugee camps and settlements in SSA $[18,19]$. These crops are often described as "drought tolerant" [20]. For example, most South Sudanese refugees left their homeland carrying a package of okra and pumpkin seeds and try to maintain meal diversity by practicing cultivation of these crops in backyards of their adopted homes in settlement and refugee camps [21,22].

Kitchen gardens may offer potential as nutrition interventions as they address a barrier almost all refugees in East Africa face when they try to access healthy foods such as fruits and vegetable $[7,21]$. This study is focused on okra which is one of the 101 crops in the African orphan crops consortium (AOCC), which aims to build a healthy Africa through nutritious, diverse and local food crops [23]. In East Africa, where refugee camps and settlements are located in marginal lands characterized by intermittent rainfall and poor soils, kitchen gardening of okra and pumpkin is a cultural practice that helps deal with food shortage and while supporting diversified food sources [19]. The agrarian South Sudanese also bring with them traditional okra production practices and adopt innovative one that include growing of the spineless okra [24]. Given that a significant portion of the refugee population across settlements and camps in East Africa are South Sudanese, it is worth noting that these settlements and camps are characterized by cultivation of okra, pumpkin and beans at garden scale. For example, participation of South Sudanese refugees in kitchen gardening in the Kalobeyei settlement (Kenya) is far higher than participation from Burundian and Ethiopian refugees [25]. Okra in addition to providing nutritious food to refugees is a source of income. For example, in the Omugu refugee settlement of Uganda, okra is one of the three crops included in contract farming for big companies by host and refugee farmers [26]. In fact, okra accounts for $25 \%$ of the most common vegetable and fruits traded within the settlement. Furthermore, South Sudanese immigrants who resettled in the USA were advised to enhance calcium intake through the consumption of "calcium-rich" food crops already common in their traditional diets, okra being one [27].

Okra is abundant shortly after the rainy season and becomes scarce during the long dry season. For off-season consumption, okra fruit slices are commonly subjected to sun-drying and stored by refugees [19]. During our visits to refugee settlement and camps in Uganda and Ethiopia we found okra being sun dried (Fig. 1, [28]). The crop/dried product is commonly eaten in the form of sauce, and also soup, with huge potential to complement aid-cereals [29, 30]. Besides its use as a nutritious food, okra also adds flavor, taste and aesthetic to a monotonous diet [30]. Okra

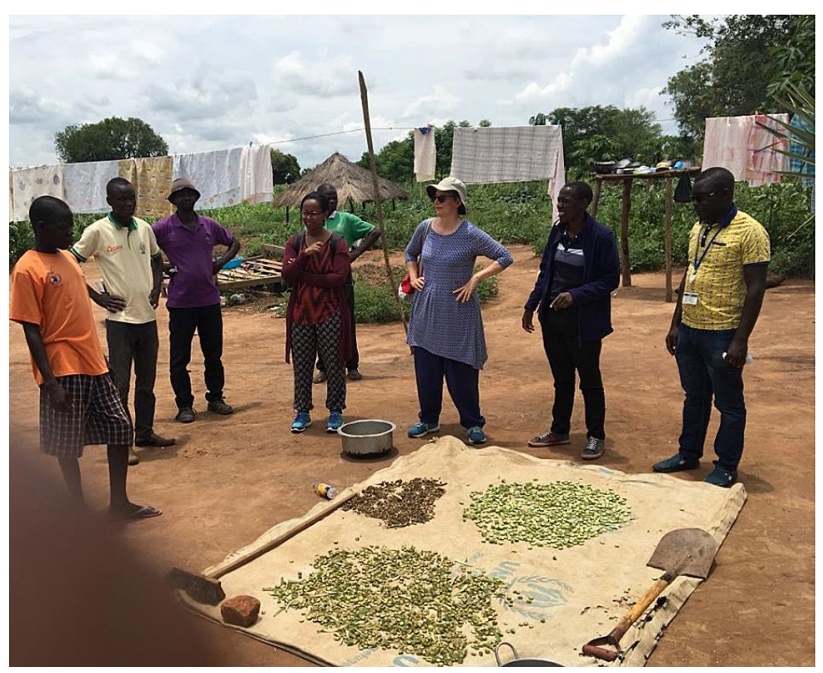

Fig. 1 Sun drying of okra by refugees in Rhino camp in Arua, Uganda 
also helps individuals re-gain dignity as well as improving cultural well-being [31].

Knowledge of the mineral content of foods is fundamental for virtually all nutrition interventions, programs and policies [32]. Similarly, the cultural acceptance of okra as a food crop indicates that it could be an important source of minerals in the diet if missing information about the mineral composition could be documented [33]. Attempts have been made to determine the mineral composition of several African food crops using various methodologies, which demonstrates varied accuracy [34-36]. For example, the standard wet laboratory procedures can reveal mineral contents as accurately as possible but wet digestion analysis is chemical intensive, laborious, expensive and time-consuming and requires well experienced technicians [33]. Typically, this has limited mineral profiling studies to a greater extent than would be ideal. Regarding East Africa, there are only a few studies that have characterized the mineral contents of okra and okra-based foods [34, 37, 38], with only one being comprehensive [34]. Moreover, the previously generated information is not holistic as a mineral composition database generated for a single agroecology cannot be applied everywhere [39]. Geographical features including soil and climate vary across localities even within the same country, which results in differences in mineral contents and quality of food crops $[39,40]$. This indicates that our knowledge of mineral composition is not complete and information available does not provide a full picture of agroecology and soil management practices in the sub-region. The current study provides unique insight into the minerals present in okra and the contribution of okra toward mineral intake in a refugee setting in East Africa. Overall, the high cost associated with wet digestion and subsequent analysis by Atomic Absorption Spectroscopy (AAS) and ICP spectrometry/spectroscopy modalities have compromised the extent of mineral profiling in staple food crops including okra across territories in SSA [41, 42]. Portable x-ray fluorescence (PXRF) represents a category of hand-held instrumentation that is capable of simultaneous multielement analysis outside the confines of a laboratory [43]. It is based on an energy dispersive principle in which dispersion of the entire spectrum occurs directly in the detector in the energy domain [44]. When a sample is scanned, the atoms within the material emit "fluorescent" $X$-rays at energies characteristic of its elemental composition [43]. Advantages of PXRF over conventional spectroscopic modalities include: (1) the use of a fast, simple and direct method [45], (2) lower equipment and consumable costs [46], (3) the avoidance of corrosive and toxic reagents [47], (4) the generation of residue of any type is nonexistent [48], (5) the capability of capturing elements in a range of forms [46, 49], and (6) no dedicated laboratory infrastructure is required [50]. In the present study, uncertainties associated with sample preparation has been partly resolved by using a homogeneous powder sample for both ICP-MS and PXRF analyses. Therefore, PXRF-based determination of minerals in culturally important food crops with acceptable accuracy could provide fast and important qualitative mineral composition information. This would also help re-orient food crop biofortification programs that aim to select the best possible accessions in terms of mineral density in the refugee context and beyond. It would also be beneficial to understand more precisely how much benefit vulnerable women and children can derive from cultivating okra. To our knowledge, this is the first study combining both mineral composition analysis and examination of the potential contribution of okra consumption to dietary reference intakes of selected minerals in a refugee context in East Africa. Another aim was to evaluate, for the first time, the applicability of PXRF as a green, direct and fast method for determination of multi-elements in dried okra powder.

\section{Materials and methods}

\subsection{Study area}

The study was carried out between November 2019 and January 2020 at four refugee camps/settlements in Ethiopia and Uganda. In Ethiopia this involved Kule ( $8^{\circ} 30^{\prime} \mathrm{S}$, $34^{\circ} 24^{\prime} \mathrm{E} ; 435 \mathrm{~m}$ altitude) and Tierkidi ( $8^{\circ} 26^{\prime} \mathrm{S}, 34^{\circ} 28^{\prime} \mathrm{E}$; $461 \mathrm{~m}$ altitude) camps located in the Gambella regional state of the country (Fig. 2). These camps host 109,817 refugees, of whom $79 \%$ are women or children under the age of 12 [51-53]. According to Kottek et al. [54] climate classification, Gambella is classified as tropical savannah (Aw) with an average temperature of $27^{\circ} \mathrm{C}$ and $1204 \mathrm{~mm}$ of average annual precipitation [55]. The most dominant soil types in the region are Vertisol, Acrisol, Fluvisol and Nitsol $[56,57]$. In Uganda this involved Rhino $\left(3^{\circ} 12^{\prime} \mathrm{S}\right.$, $31^{\circ} 22^{\prime} \mathrm{E} ; 711 \mathrm{~m}$ altitude) and Imvepi ( $3^{\circ} 20^{\prime} \mathrm{S}, 31^{\circ} 27^{\prime} \mathrm{E}$; $629 \mathrm{~m}$ altitude) settlements located in the Arua district and accommodate a total of 190,742 refugees, of whom $82 \%$ are women or children (Fig. 3). Arua is the second most populous refugee hosting district in the country [58, 59]. Its climate is classified as tropical savannah (Aw) by Kottek et al. [54] with an average temperature of $23^{\circ} \mathrm{C}$ and $1400 \mathrm{~mm}$ of average annual precipitation [60]. Entisols is the predominant soil type in the district [61]. It was critical to include samples from two countries and several sites to account for possible differences in agronomic, geographic and water conditions that could have impacted the mineral content of the okra crop. In the four camp and settlements South Sudanese represented over $95 \%$ of the 


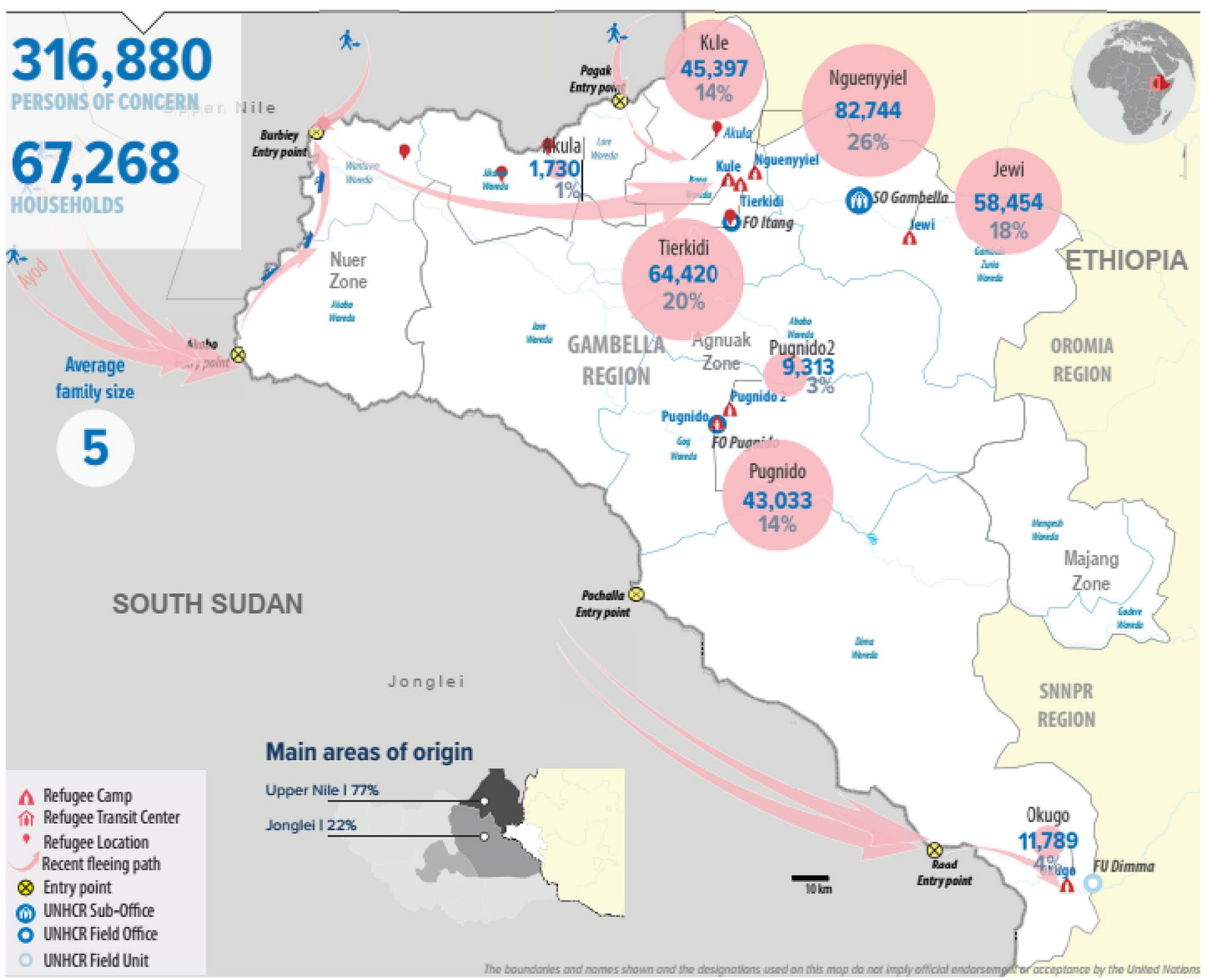

Fig. 2 Refugee population in Gambella region, Ethiopia [53]

refugee population (Table 1). Of the many countries in SSA that have suffered displacement, South Sudan is amongst the most severely affected [24].

\subsection{Sample collection and preparation}

A total of 48 okra pod samples were collected from 4 prominent refugee settlements and camps in East Africa: Kule and Tierkidi in Ethiopia and Rhino and Imvepi in Uganda (Figs. 2 and 3). Sampling was partly constrained by the scarcity of standing okra trees during the period when sampling was undertaken. Briefly, each sample was collected in either of the following forms: (1) fresh pods were hand-picked from the standing plants (trees), each sample represented by a pooled sample of 4-5 okra pods, and they were made into a single composite sample and later processed, and (2) okra pods (sun-dried) stored for off-season consumption, approximately equivalent to 4-5 fresh pods, were kindly provided by refugees at a specific zone/unit. In detail, 24 samples were collected from refugee camps in Ethiopia ( 12 from Kule and 12 from Tierkidi) and another 24 were obtained from settlements in Uganda (13 from Rhino, and 11 from Imvepi). Samples were further oven dried at $65^{\circ} \mathrm{C}$ to constant weight and pulverized using a Sayona blend grinder (China) and labeled with proper code number in plastic sealed bags. Later, samples were transported to the University of Jaen (Jaen, Spain) and Mount Allison University (Sackville, Canada) for ICPMS and PXRF analysis, respectively.

\subsection{Chemicals and reagents}

All reagents and standards were of analytical reagent grade. Ultrapure water was produced with a Milli-Q water 


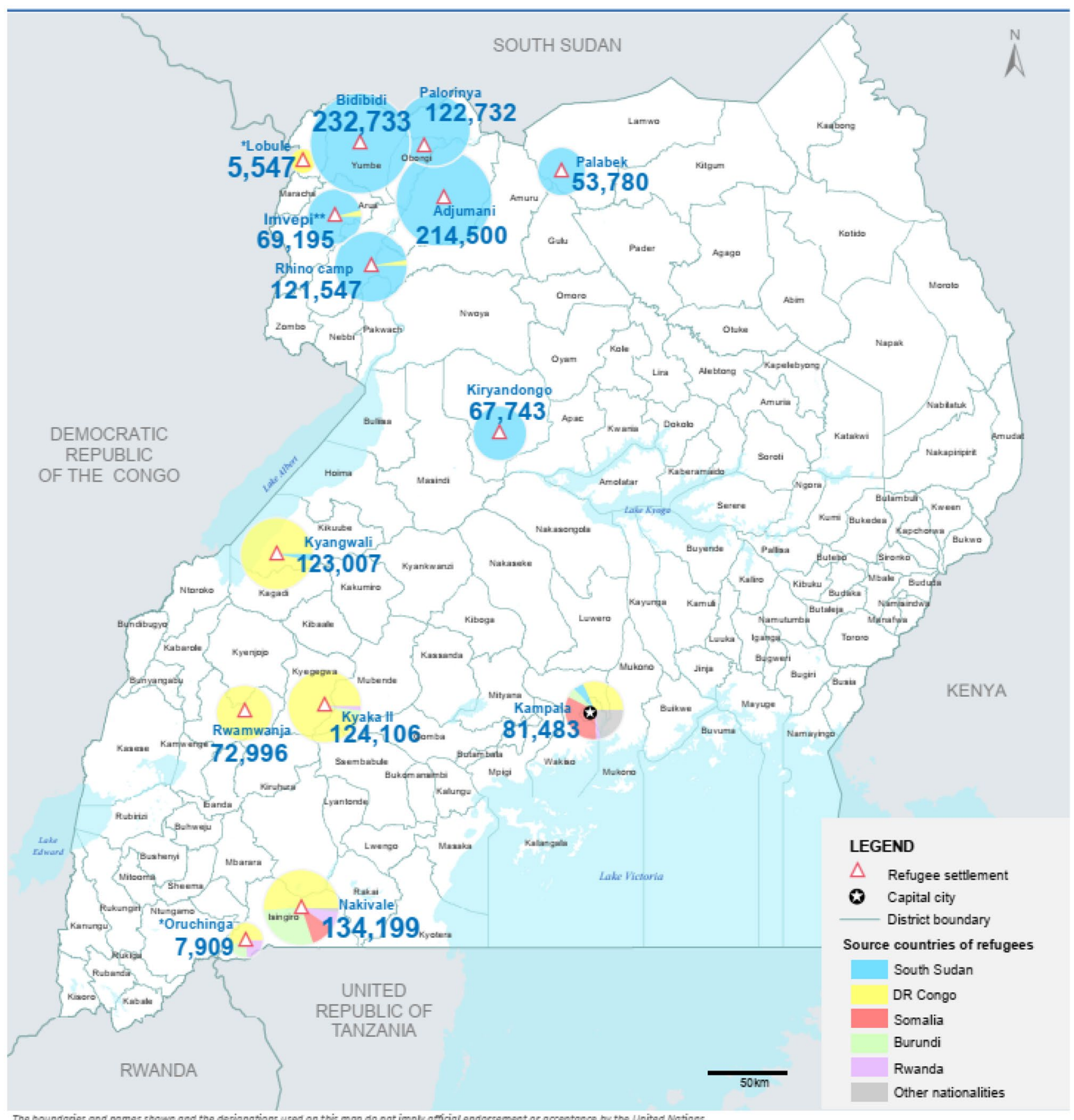

Fig. 3 Refugee population in Uganda [59]

purification system (Millipore, Bedford, MA, USA). 65\% $\mathrm{HNO}_{3}$ was purchased from Sigma (Madrid, Spain) and $\mathrm{HNO}_{3}$ was further purified by sub-boiling distillation with a still built up with components from Savillex (ISC Science; Oviedo, Spain). Standard reference material (Cranberry fruit, NIST-3281) was provided by the National Institute of Standards and Technology (Gaithersburg, MD, USA). The following reagents were also used for the preparation of the calibration standard solutions: a $100 \mu \mathrm{g} \mathrm{mL}^{-1}$ multi-element standard solution from High-Purity Standards (Charleston, SC, USA) and an internal standard kit solution from ISC Science (Oviedo, Spain).

\subsection{Sample digestion and analysis}

For total element analyses, sub-samples were taken from each composite sample. Approximately $0.2 \mathrm{~g}$ of individual sub-samples were digested with $3 \mathrm{~mL} \mathrm{HNO}$ in $15 \mathrm{~mL}$ 
Table 1 UNHCR refugee population characteristics (\%) in the study refugee camps and settlements in Ethiopia and Uganda

\begin{tabular}{|c|c|c|c|c|}
\hline \multirow[t]{2}{*}{ Country of origin } & \multicolumn{2}{|l|}{ Ethiopia } & \multicolumn{2}{|c|}{ Uganda } \\
\hline & Tierkidi & Kule & Rhino & Imvepi \\
\hline South Sudan & 99.99 & 99.99 & 96.81 & 95.92 \\
\hline $\begin{array}{l}\text { Democratic Republic } \\
\text { of Congo }\end{array}$ & - & - & 2.45 & 4.04 \\
\hline Others & 0.0000 & 0.01 & 0.74 & 0.04 \\
\hline
\end{tabular}

Source: [62-65]

digestion vessels using a single-reaction chamber system (UltraWave ${ }^{\mathrm{T}}{ }^{\mathrm{M}}$, Milestone). The conditions used for the microwave digestion were: a) $5 \mathrm{~min}$ at $100^{\circ} \mathrm{C}$, b) $7 \mathrm{~min}$ at $150^{\circ} \mathrm{C}$, c) $8 \mathrm{~min}$ at $180^{\circ} \mathrm{C}$, d) $5 \mathrm{~min}$ at $220^{\circ} \mathrm{C}$, and e) $15 \mathrm{~min}$ at $220^{\circ} \mathrm{C}$. After cooling to room temperature, the aliquots were transferred to metal-free ICP-MS vials and brought to $25 \mathrm{~mL}$ with ultra-pure water. Elemental analyses were carried out by using an Agilent 7900 ICP-MS (Agilent Technologies, CA, USA) equipped with a Peltier-cooled quartz spray chamber (Scott type), a quartz torch ( $2.5 \mathrm{~mm}$ i.d.), and a low flow concentric nebulizer $(0.2 \mathrm{~mL} / \mathrm{min})$. The ICPMS operating conditions are presented in Table S1. Calibration graphs were prepared between 0.1 and $10,000 \mu \mathrm{g} \mathrm{L}^{-1}$. The detection limit (DL) and quantification limit (QL) were calculated as the concentration that provided 3 and 10 times the signal of the blank for each element. We report the method DLs (DLs in real samples, including sample treatment) (Table S2).

Since no certified reference material (CRM) is available for okra, the validity and reliability of the analytical results were ensured by determining the elemental concentration in Cranberry fruit standard reference material (NIST-3281) in the same way as the samples. Several studies have validated the accuracy of ICP-based methods for determination of minerals using this CRM $[33,66,67]$. The certificate concentrations considerably agreed with the measurement concentrations and no significant differences were observed between these values, demonstrating the accuracy of the analytical methodology used in the present study. Recovery experiments were also performed during each analytical batch, observing satisfactory recovery yields. All composite samples were analyzed in duplicate and the relative standard deviations (RSD) were less than $15 \%$.

\subsection{PXRF analysis}

Determination of multiple elements was performed using an HD Mobile X-ray fluorescence system (X-ray Optical Systems; East Greenbush, NY, USA) equipped with a molybdenum X-ray target, an X-ray tube current of $200 \mu \mathrm{A}$, and a tube voltage of up to $50 \mathrm{kV}$. The use of a molybdenum target is the most practical option for exciting a wide range of elements using a single system [68]. The radiation detector is a silicon drift detector with a diameter of $25 \mathrm{~mm}$. For each measurement, a powdered okra fruit sample was analyzed by placing it first in an X-ray fluorescence sample cell (SCP Science, Canada), sealed with a $4 \mu \mathrm{m}$-thick prolene film. The sample was then positioned on the platform directly above the X-ray beam window. Each sample had an approximate mass of $0.4 \mathrm{~g}$. X-ray beam profiles and $X$-ray fluorescence measurement time (30 s real time) have been described elsewhere [33]. Each sample was measured three times, with no sample repositioning between measurements. A total of $144\left(48^{*} 3\right)$ measurements were made in this fashion. Concentrations for various elements were output directly from the HD Mobile system, based on manufacturer-provided calibrations. While it is not expected that the concentrations output from the system will be accurate for the particular matrix used in this study, the results should be reflective of the true concentrations in a relative sense. We used the "low energy" beam results for $\mathrm{K}$ and $\mathrm{Ca}$, and the "high energy" beam results for $\mathrm{Mn}$, Fe and Zn.

\subsection{Estimation of okra consumption to AI/RDA for minerals}

Although okra is largely cultivated by South Sudanese refugees, its consumption is scarcely documented. We do know that okra consumption by South Sudanese refugees is higher than refugees of other nationalities including Somalis, Burundians, Ethiopians, and Congolese $[25,69]$. This clearly portrays South Sudanese as an okra-consuming population. We focused on South Sudanese because this nationality comprised $99.99 \%, 99.99 \%$, $96.81 \%$ and $95.92 \%$ of the population of the Tierkidi, Kule, Rhino and Imvepi refugee camps/settlements, respectively. Since no information regarding per capita consumption of okra in a refugee setting and beyond is available, estimation of per capita okra consumption is based on per capita fruit and vegetable consumption and household demand for the crop. According to Relief International [69], the highly demanded vegetable and fruits by the refugee and host community households in Upper Nile (South Sudan) follows the order: okra (1st), kudera (2nd) and eggplant (3rd). Okra accounts for $25 \%$ of the most common vegetable and fruits traded within the Batil and Doro refugee camps. On the other hand, the per capita fruit and vegetable consumption is reported to be $675 \mathrm{~g} \mathrm{day}^{-1}$ [70]. For PLW, 25\% of the per capita vegetable consumption is considered as high-end okra consumption probability since okra accounts for $25 \%$ of the most common traded vegetable and highly 
consumed crop. Whereas, one-tenth of the per capita vegetable consumption is considered as low-end okra consumption probability.

Specific fruit intake recommendation calls for approximately $170 \mathrm{~g} \mathrm{day}^{-1}$ for young children according to dietary guidelines for Americans [71]. Thus, $25 \%$ of the per capita fruit consumption is considered as high-end okra consumption probability and $10 \%$ of the per capita fruit consumption is considered as low-end okra consumption probability for young children aged between 1 and 3 years. Therefore, the following assumptions have been made: $17 \mathrm{~g}$ and $68 \mathrm{~g}$ fresh okra are assumed as standard portions for young children aged between 1 and 3 years, and pregnant and lactating women aged between 19 and 30 years, respectively (low-end consumption probabilities) and $42 \mathrm{~g}$ and $169 \mathrm{~g}$ fresh okra are assumed as standard portions for young children aged between 1 and 3 years, and pregnant and lactating women aged between 19 and 30 years, respectively (high-end consumption probabilities) were considered as daily portions.

The moisture content in okra pods were also reported to vary greatly depending on variety, stages of maturity and geographical origin [34, 72]. In the present study, okra pod was assumed to exhibit $80 \%$ moisture content [73]. Furthermore, the World Health Organization (WHO) recommends a daily intake of fruits and vegetables, roughly equal to 400-600 g, which may prevent diet-related noncommunicable diseases [74]. Daily intake levels of macro and micro-minerals associated with okra consumption were estimated and compared with AI/RDA values for selected life stages (young children aged between 1 and 3 years and PLW aged between 19 and 30 years) as commended by the Institute of Medicine (IOM) [75-77]. We used these life stages because they are nutritionally the most vulnerable and also represent a considerable portion of the refugee composition in East Africa.

\subsection{Statistical analysis}

Data were analyzed using Statistical Package for Social Sciences (SPSS) version 23. Distribution of ICP-MS data was summarized and presented using box plot analysis. The normal distribution and homogeneity of variance were tested using Kolmogorov-Smirnov's and Levene's tests, respectively. For $\mathrm{P}, \mathrm{Fe}, \mathrm{Zn}, \mathrm{Mn}$ and $\mathrm{Cu}$, Mann-Whitney non-parametric test was employed to evaluate statistical difference in median content of okra between the two countries. The paired t-test, non-parametric test, Relative standard deviation (RSD) and $R^{2}$ were employed to assess PXRF data quality and level of agreement with the reference method (ICP-MS) $[45,78]$. Statistical significance was established at $p<0.05$.

\section{Results}

\subsection{Mineral composition}

Median and interquartile range values (Q1-Q3) for macro minerals and microminerals in 48 composite okra samples from four refugee camps and settlements in East Africa are shown in Fig. 4. The $\mathrm{K}$ contents varied greatly with a range of $14,385-33,294 \mathrm{mg} \mathrm{kg}^{-1}$ but doesn't reflect significant $(p=0.928)$ geographical variation in okra grown in refugee camps and settlements in East Africa (Fig. 4). Calcium was also an abundant macro mineral. The Ca content in okra pod varied between 2610 and $14,090 \mathrm{mg} \mathrm{kg}^{-1}$. Statistically, the highest median P concentration was obtained from okra grown in refugee camps in Ethiopia. The range of concentration for $\mathrm{Mg}$ in okra pod samples was: $3896-7986 \mathrm{mg} \mathrm{kg}^{-1}$. The median Fe contents were $110-287 \mathrm{mg} \mathrm{kg}^{-1}$ for Ethiopia and Uganda, respectively. The highest Fe level, $1243 \mathrm{mg} \mathrm{kg}^{-1}$, was obtained from the Imvepi refugee settlement in Uganda and the difference was significant between geographic origins. As shown in Fig. 4, the contents of $\mathrm{Zn}$ ranged from 33 to $141 \mathrm{mg} \mathrm{kg}^{-1}$. The median content of $\mathrm{Zn}$ in okra samples from the Tierkidi and Kule refugee camps was statistically higher than those obtained from the Rhino and Imvepi refugee settlements in Uganda. For $\mathrm{Mn}$, a significant variation between geographic origins was also observed, in which Ethiopian okra exhibited higher concentrations than Ugandan okra with median values of 62.5 and $30 \mathrm{mg} \mathrm{kg}^{-1}$, respectively. Similarly, okra contained relatively lower Cu levels, ranging from 3.81 to $19.3 \mathrm{mg} \mathrm{kg}^{-1}$.

\subsection{Contribution to mineral reference intake or dietary allowance}

The potential contributions of okra consumption for $\mathrm{Al} / \mathrm{RDA}$ of four macro minerals $(\mathrm{K}, \mathrm{Ca}, \mathrm{P}$ and $\mathrm{Mg})$ and four micro minerals ( $\mathrm{Mn}, \mathrm{Fe}, \mathrm{Cu}$ and $\mathrm{Zn}$ ) were estimated (Table 2). Based on Al for K, consumptions of okra could offer a percentage contribution ranging from 2.6 to 6.8 for young children and 6.3-17.4 for PLW. As far as lowend consumption probability for okra grown in refugee camps from Ethiopia is concerned, potential contributions to $\mathrm{Al}$ for $\mathrm{Ca}$ are $4.3 \%$ and $8.6 \%$ for young children and PLW, respectively. Whereas, at high-end consumption probability, contributions to Al for Ca could increase to $10.7 \%$ and $21.4 \%$ for young children and PLW, respectively. Considering refugee settlements in Uganda, the contribution to Al for Ca from okra consumption could even be higher for both young children $(6.4 \%$ (low-end 


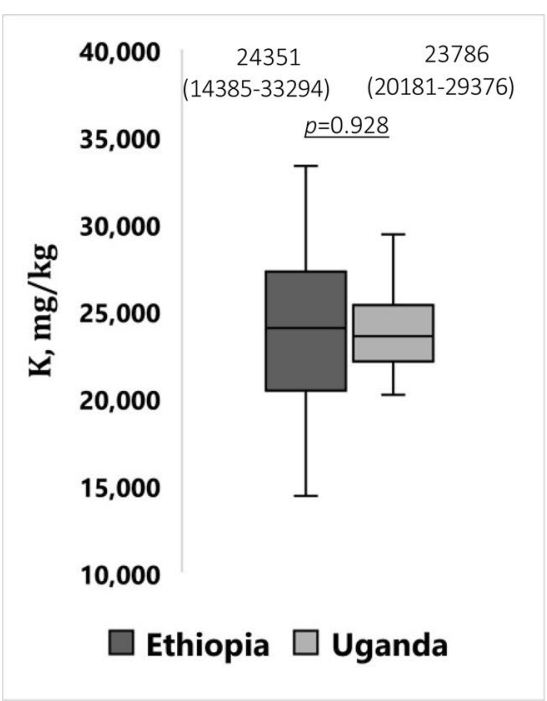

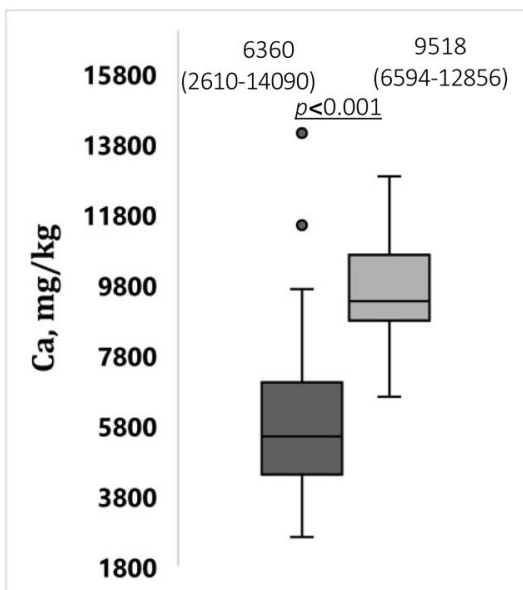

$\square$ Ethiopia $\square$ Uganda

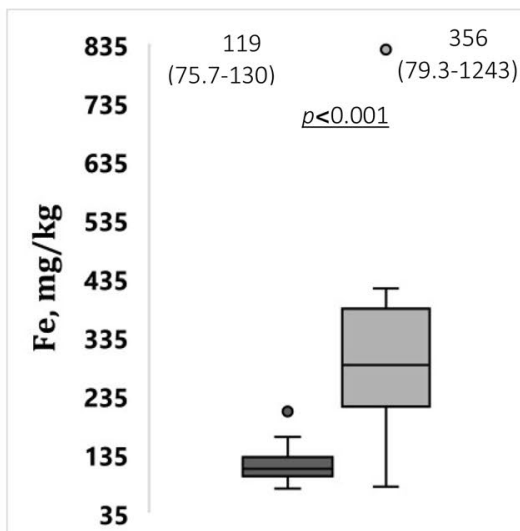

Ethiopia $\square$ Uganda
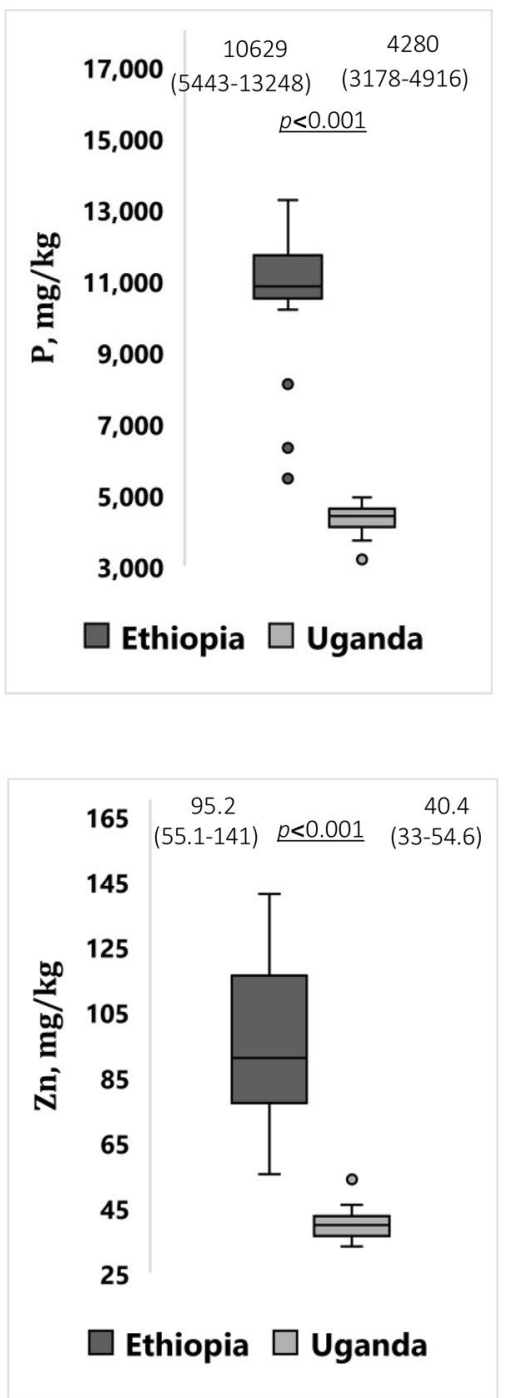
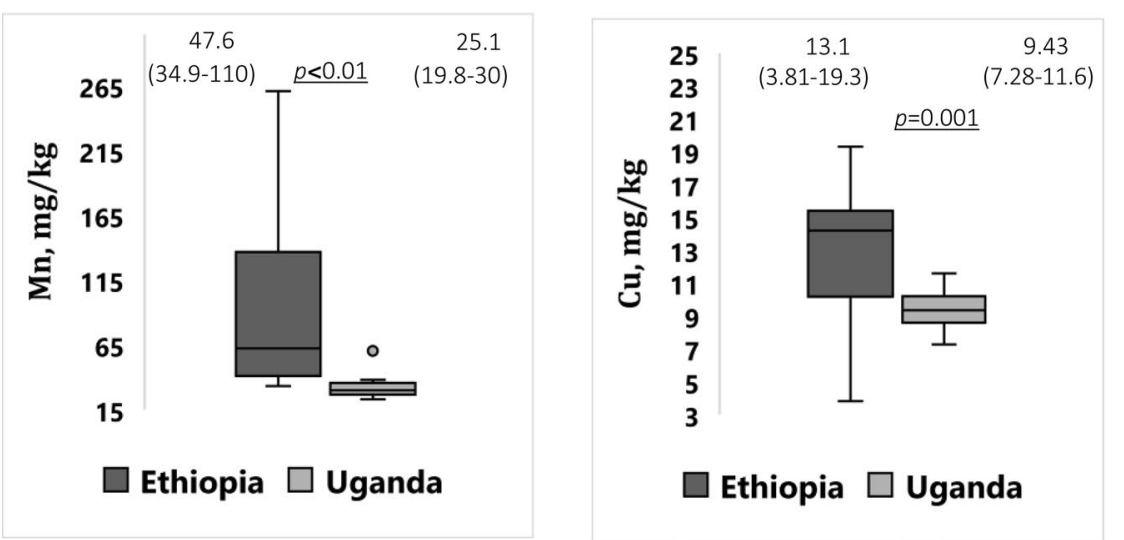

Fig. 4 Box plots of ICP-MS measurements for elemental contents ( $\mathrm{mg} \mathrm{kg}^{-1} \mathrm{dw}$ ) of okra from refugee settlements and camps in East Africa. The values at the top indicate the mean and the range. The line in each box represents the median concentration result, while the bottom and top of the box signify the first and third quartiles, respectively. The whiskers are the lines that extend from the bottom and top of the box to lower and upper bounds calculated from the data. Values outside these limits represent outliers 
Table 2 Percentage contribution to $\mathrm{Al} / \mathrm{RDA}$ through the consumption of $68 \mathrm{~g}$ and $17 \mathrm{~g}$ fresh okra by PLW aged between 19 and 30 years and young children aged between 1 and 3 years, respectively (low-end consumption probabilities) and the consumption of $169 \mathrm{~g}$ and $42 \mathrm{~g}$ fresh okra by PLW aged between 19 and 30 years and infants aged between 1 and 3 years, respectively (high-end consumption probabilities), in a refugee context in East Africa. The estimation is based on ICP-MS data

\begin{tabular}{|c|c|c|c|c|c|}
\hline \multirow[t]{2}{*}{ Mineral } & \multicolumn{2}{|l|}{$\mathrm{Al}^{\mathrm{\alpha}} / \mathrm{RDA}$} & \multirow[t]{2}{*}{ Consumption probability } & \multicolumn{2}{|c|}{$\%$ contribution } \\
\hline & Life stages & $\mathrm{mg} /$ person/day & & Ethiopia & Uganda \\
\hline \multirow[t]{6}{*}{$K^{a}$} & Children & 3000 & Low-end consumption probability & 2.8 & 2.7 \\
\hline & & & High-end consumption probability & 6.8 & 6.7 \\
\hline & Pregnancy & 4700 & Low-end consumption probability & 7.0 & 6.9 \\
\hline & & & High-end consumption probability & 17.4 & 17.1 \\
\hline & Lactation & 5100 & Low-end consumption probability & 6.5 & 6.3 \\
\hline & & & High-end consumption probability & 16.2 & 15.7 \\
\hline \multirow[t]{6}{*}{$\mathrm{Ca}^{\mathrm{a}}$} & Children & 500 & Low-end consumption probability & 4.3 & 6.4 \\
\hline & & & High-end consumption probability & 10.7 & 15.9 \\
\hline & Pregnancy & 1000 & Low-end consumption probability & 8.6 & 12.9 \\
\hline & & & High-end consumption probability & 21.4 & 32.1 \\
\hline & Lactation & 1000 & Low-end consumption probability & 8.6 & 12.9 \\
\hline & & & High-end consumption probability & 21.4 & 32.1 \\
\hline \multirow[t]{6}{*}{$\mathrm{P}$} & Children & 460 & Low-end consumption probability & 8.0 & 3.2 \\
\hline & & & High-end consumption probability & 19.8 & 8.0 \\
\hline & Pregnancy & 700 & Low-end consumption probability & 21 & 8.5 \\
\hline & & & High-end consumption probability & 52.3 & 21.2 \\
\hline & Lactation & 700 & Low-end consumption probability & 21 & 8.5 \\
\hline & & & High-end consumption probability & 52.3 & 21.2 \\
\hline \multirow[t]{6}{*}{$\mathrm{Mg}$} & Children & 80 & Low-end consumption probability & 28.5 & 20.2 \\
\hline & & & High-end consumption probability & 70.5 & 49.7 \\
\hline & Pregnancy & 350 & Low-end consumption probability & 26.1 & 18.4 \\
\hline & & & High-end consumption probability & 64.8 & 45.7 \\
\hline & Lactation & 310 & Low-end consumption probability & 29.5 & 20.8 \\
\hline & & & High-end consumption probability & 57.4 & 40.5 \\
\hline \multirow[t]{6}{*}{$\mathrm{Mn}^{\mathrm{a}}$} & Children & 1.2 & Low-end consumption probability & 17.7 & 8.5 \\
\hline & & & High-end consumption probability & 43.8 & 21 \\
\hline & Pregnancy & 2 & Low-end consumption probability & 42.5 & 20.4 \\
\hline & & & High-end consumption probability & 106 & 50.7 \\
\hline & Lactation & 2.6 & Low-end consumption probability & 32.7 & 15.7 \\
\hline & & & High-end consumption probability & 81.3 & 39 \\
\hline \multirow[t]{6}{*}{$\mathrm{Fe}$} & Children & 7 & Low-end consumption probability & 5.3 & 14 \\
\hline & & & High-end consumption probability & 13.2 & 34.7 \\
\hline & Pregnancy & 27 & Low-end consumption probability & 5.5 & 14.5 \\
\hline & & & High-end consumption probability & 13.7 & 36 \\
\hline & Lactation & 9 & Low-end consumption probability & 16.6 & 43.4 \\
\hline & & & High-end consumption probability & 41.3 & 108 \\
\hline \multirow[t]{6}{*}{$\mathrm{Zn}$} & Children & 3 & Low-end consumption probability & 10.3 & 4.5 \\
\hline & & & High-end consumption probability & 25.4 & 11.1 \\
\hline & Pregnancy & 11 & Low-end consumption probability & 11.2 & 4.9 \\
\hline & & & High-end consumption probability & 27.8 & 12.1 \\
\hline & Lactation & 12 & Low-end consumption probability & 10.3 & 4.5 \\
\hline & & & High-end consumption probability & 25.6 & 11.1 \\
\hline \multirow[t]{6}{*}{$\mathrm{Cu}$} & Children & 0.34 & Low-end consumption probability & 14.2 & 9.4 \\
\hline & & & High-end consumption probability & 35.1 & 23.1 \\
\hline & Pregnancy & 1 & Low-end consumption probability & 19.3 & 12.7 \\
\hline & & & High-end consumption probability & 48 & 31.6 \\
\hline & Lactation & 1.3 & Low-end consumption probability & 14.9 & 9.8 \\
\hline & & & High-end consumption probability & 36.9 & 24.3 \\
\hline
\end{tabular}

Al (adequate intake) or RDA (recommended dietary allowance) established by the Food and Nutrition Board of the Institute of Medicine (IOM) [75-77] 
consumption probability) and $15.9 \%$ (high-end consumption probability)) and PLW (12.9\% (low-end consumption probability) and $32.1 \%$ (high-end consumption probability)). Considering $\mathrm{P}$, the contribution by okra grown in Ethiopia could be higher than okra grown in Uganda.

Irrespective of life stages and consumption probabilities, okra grown in refugee camps in Ethiopia could contribute to greater than $20 \%$ of RDA for $\mathrm{Mg}$. Yet, at high-end consumption probability, East African okra could increase the intake of Mg strongly: $49.7-70.5 \%$ and $40.5-64.8 \%$ for young children and PLW, respectively. In refugee settlements and camps in Ethiopia and Uganda, okra might contribute less than $15 \%$ of RDA for Fe during young age and pregnancy. However, at high-end consumption probability, Ugandan okra could contribute adequately to the RDA of Fe for young children and PLW (14-108\%). Somewhat lower contributions to RDA for $\mathrm{Zn}$ could be obtained from okra consumption at different consumption probabilities and life stages in refugee settlements located in Uganda. Regardless of geographic origin, okra could contribute sufficiently to $\mathrm{Mn}$ and $\mathrm{Cu}$ at both low-end and high-end consumption probabilities.

\subsection{Comparison of ICP-MS with PXRF}

The paired t-test ( $\mathrm{K}$ and $\mathrm{Ca}$ ) and Mann-Whitney non-parametric test ( $\mathrm{Fe}, \mathrm{Zn}$ and $\mathrm{Mn}$ ) indicated that there were no significant differences between ICP-MS and PXRF measurements. The RSD obtained for PXRF and ICP-MS-determined concentrations of $\mathrm{K}, \mathrm{Ca}, \mathrm{Fe}, \mathrm{Zn}$ and $\mathrm{Mn}$ were between $9.4 \%$ and $27.7 \%$ (Table 3 ). Figure 5 shows regression curves for correlation between the concentrations obtained by PXRF against the concentrations obtained by ICP-MS (reference method) for $\mathrm{K}, \mathrm{Ca}, \mathrm{Fe}, \mathrm{Zn}$ and $\mathrm{Mn}$. The $\mathrm{R}^{2}$ values of the regression analysis were 0.92 and 0.96 for $\mathrm{Zn}$ and $\mathrm{Mn}$, respectively, demonstrating excellent agreement between ICP-MS and PXRF-determined concentrations. On the other hand, lower levels of conformity between ICP-MS and PXRF-determined concentrations were observed for $\mathrm{K}$ $\left(R^{2}=0.27\right), \mathrm{Ca}\left(R^{2}=0.66\right)$ and $\mathrm{Fe}\left(R^{2}=0.69\right)$. Regarding these minerals, the sample sets encompass RSD value $>10 \%$ (13.7\% for $\mathrm{K}, 16.4 \%$ for $\mathrm{Ca}$ and $27.7 \%$ for $\mathrm{Fe}$ ).

\section{Discussion}

\subsection{Mineral composition}

Deficiencies of minerals have become a major health challenge, in which malnutrition associated with $\mathrm{Fe}, \mathrm{Zn}$ and lodine impacts a considerable portion of the population in SSA $[5,79]$. Depending on which minerals are lacking, low intakes can have several negative health effects including stunting, anemia, and cognitive impairments in children [80,81]. Of the most concern in a refugee context are $\mathrm{Fe}$ and $\mathrm{Zn}$ due to high reliance on cereal-based relief foods as the main components of a daily ration $[5,6]$. For example, SSA harbors $91 \%$ of the world's hidden hungeraffected pre-school children [82]. On the other hand, SSA is bestowed with immense diversity of under-utilized orphan crops [83]. Although these crops hold huge potential in terms of food and nutrition security and are reported to adapt in changing climatic conditions, to date, they are researched scarcely $[16,84]$. So, scientific and technological advancement associated with nutritional status of culturally important orphan crops could contribute substantially to inform existing and anticipated future nutrition response. One such initiative is the ambitious genome sequencing of 101 African orphan crops with the aim to build a nutritious and healthy Africa within a huge project co-led by World Agroforestry [83]. In this regard, multi-mineral analysis of orphan fruits and vegetables grown across various agro-ecologies may help estimate the potential contributions for mineral adequacy in a refugee context and beyond.

In this study, the ICP-MS results differed significantly between the countries for a range of minerals except $\mathrm{K}$. Knowing that very few studies have assessed the mineral composition of okra in East Africa, and perhaps none in a refugee context, sub-region comparison is challenging. For example, Gemede et al. [34] revealed considerable
Table 3 Quality levels of the PXRF data based on the US EPA's quality ranking [78]

\begin{tabular}{lccccl}
\hline Analyte & $\begin{array}{c}\text { ICP-MS- determined con- } \\
\text { centration range }\left(\mathrm{mg} \mathrm{kg}^{-1}\right)\end{array}$ & $\begin{array}{l}\text { PXRF- determined concen- } \\
\text { tration range }\left(\mathrm{mg} \mathrm{kg}^{-1}\right)\end{array}$ & RSD & Data quality level \\
\hline $\mathrm{K}$ & $14,385-33,294$ & $9768-37,226$ & 0.27 & 13.7 & Qualitative \\
$\mathrm{Ca}$ & $2610-14,090$ & $1851-15,402$ & 0.66 & 16.4 & Qualitative \\
$\mathrm{Fe}$ & $75.7-1243$ & $36-745$ & 0.69 & 27.7 & Qualitative \\
$\mathrm{Zn}$ & $33-141$ & $18.9-132$ & 0.92 & 10 & Definitive \\
$\mathrm{Mn}$ & $23.1-261$ & $17.8-190$ & 0.96 & 9.4 & Definitive \\
\hline
\end{tabular}

Total number of paired samples in which both the ICP-MS and PXRF analyzers detected the specified analyte were 48 
Fig. 5 Regression curves correlating the ICP-MS and PXRF measurements for $\mathrm{K}, \mathrm{Ca}, \mathrm{Fe}, \mathrm{Zn}$ and $\mathrm{Mn}\left(\mathrm{mg} \mathrm{kg}^{-1} \mathrm{dw}\right)$

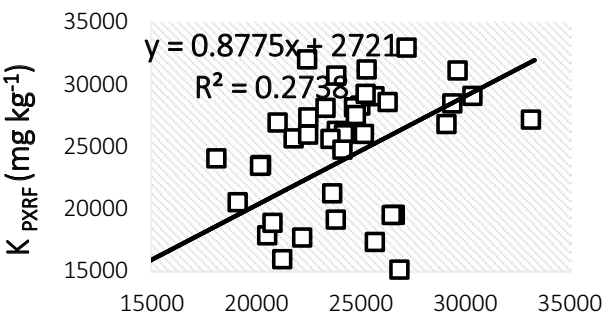

$\mathrm{K}_{\text {ICP-MS }}\left(\mathrm{mg} \mathrm{kg}^{-1}\right)$

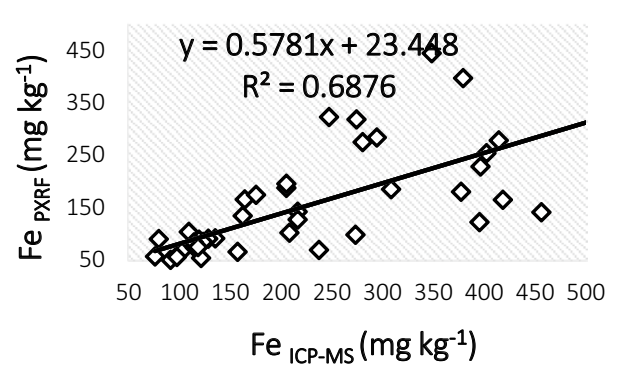

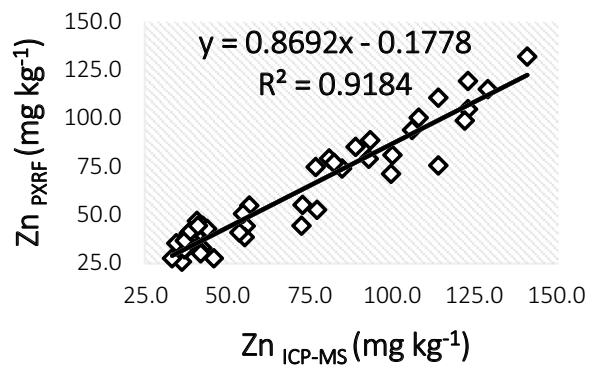

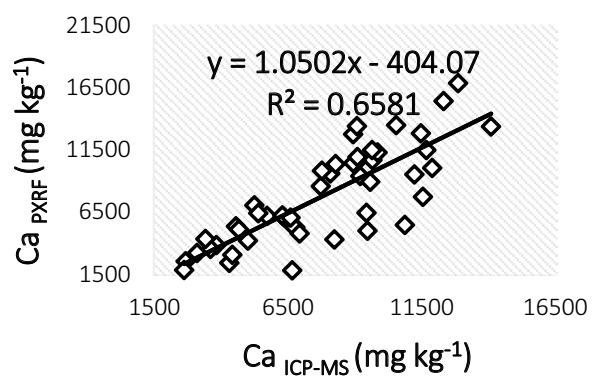

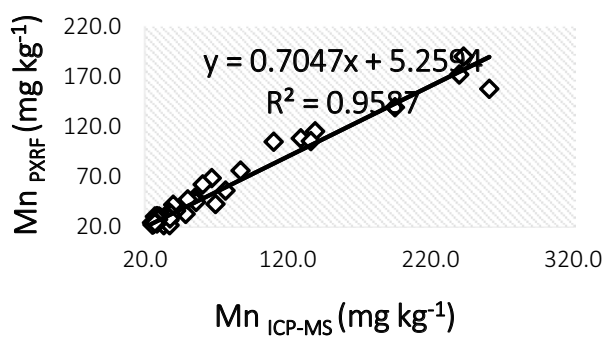

differences for $\mathrm{Ca}, \mathrm{P}, \mathrm{Mg}$, Fe and $\mathrm{Zn}$ among local accessions. In fact, genotypic difference along with environment and farming conditions have significant influence on elemental composition of okra in the Mediterranean region [85]. As studies conducted in East Africa have been very limited, the results of the present study have been compared with studies conducted elsewhere particularly Western and Southern Africa. Regardless of origin, the abundance of minerals follows the order: $\mathrm{K}>\mathrm{Ca}>\mathrm{P}>\mathrm{Mg}>\mathrm{Fe}>\mathrm{Zn}>\mathrm{Mn}$ $>\mathrm{Cu}$. Similar order of abundance was observed by Kehinde et al. [30] except a drop in Mg.

Regardless of geographic origin, $\mathrm{K}$ was the most abundant macro mineral. Similar results have been reported by several studies in SSA $[37,38,86]$. In contrast, lower $\mathrm{K}$ content was reported for okra pod from Nigeria [30]. Moreover, traditional okra-based sauce commonly consumed in the far north region of Cameroon exhibited comparable levels of $\mathrm{K}$ [87]. Calcium is also indispensable to human body [88]. Calcium contents in okra in this study has not surpassed literature data from Zimbabwe [89], and Benin [38]. Okra-based sticky sauce also contained comparable amounts of $\mathrm{Ca}$ [87]. However, Petropoulos et al. [90] and Petropoulos et al. [85] revealed higher amounts of Ca in okra pods and seeds than what has been found in the present study. Conversely, Kehinde et al. [30] and Ferguson et al. [86] reported far lower contents of this mineral, approximately five to nine times lower than what has been reported in the present study. The elevation in $\mathrm{Ca}$ in the present study might be ascribed to the inclusion of seeds [90-92]. Among fruit and vegetable crops, okra is typically reported to have higher level of $P$ [89]. Statistically, lowest mean content $\left(4280 \mathrm{mg} \mathrm{kg}^{-1}\right)$ of $P$ in okra was attributed to samples collected from refugee settlements in Uganda. Similar observations indicating $\mathrm{P}$ content between 3800 and $6160 \mathrm{mg} \mathrm{kg}^{-1}$ were reported by Chitsiku [89], Ferguson et al. [86] and Mitchikpe [37]. The present study revealed that okra is a good source of Mg. The same observation was made by Mitchikpe [37] in dried okra pod from Benin. In fact, okra leaves provide an additional source of magnesium when consumed together with the okra pod [37].

$\mathrm{Mn}$ is ubiquitous in foods and its deficiency is highly unlikely [93]. The median contents of Mn were consistent with the values obtained from Benin [37]. In contrast, we reported higher contents of $\mathrm{Mn}$ than obtained by Kehinde et al. [30]. Moreover, our values are far higher than those reported for okra-corn paste in Cameroon [94]. Green leaves are usually considered as the plant source of $\mathrm{Fe}$ 
$[95,96]$. It is interesting to note that we found comparable Fe content in okra pods from refugee settlements (Uganda) to those of green leaves particularly traditional leafy vegetables [97-99]. This implies that okra pods could be mixed with the cereals supplied to refugees. Gemede et al. [34] reported higher levels of Fe (183-367 $\mathrm{mg} \mathrm{kg}^{-1}$ ) in okra accessions collected from western Ethiopia. Similarly, higher Fe content $\left(566 \mathrm{mg} \mathrm{kg}^{-1}\right.$ ) was reported for dried okra pods used for popular sauce preparation in Sahelian Africa [100]. The elevation in Fe in that setting is ascribed to the inclusion of seeds [101]. Zinc is a co-factor for many enzymes and helps maintain structural integrity of proteins and reduce infections [102]. Previous studies reported similar ranges for $\mathrm{Zn}$ in dried okra pods and okrabased sauce $[100,103]$. In fact, okra was shown to be a good source of digestible zinc. Differential potentials for uptake and accumulation among varieties and genotypes may account for varied reported results [92, 104]. Among the micro-minerals, Cu was obtained in the lowest concentrations. The reported contents were in good agreement with the literature values obtained in dried okra pod and okra-based sauce in SSA $[37,105]$. Aside from the contribution of varietal and environmental differences, the difference in mineral profile could be ascribed to the inclusion of seeds or seedless pods [90]. In fact, okra seeds, which represent about $13.5 \%$ of dried okra [34, 106, 107], are a rich source of minerals $[91,92]$. For example, okra seeds have been reported to contain a $\mathrm{K}$ content as high as $40 \mathrm{~g} \mathrm{~kg}^{-1}$ [90].

Generally, the median mineral contents in the okra pod samples were lower than the contents presented elsewhere $[85,108]$. This was expected due to the marginal fertility nature of lands used to establish refugee camps and settlements in East Africa. It is also partly explained by the differences in agroecology and adaptability of cultivars as well as the difference in genetic potential. In fact, the mineral contents of okra tend to decrease with no fertilizing material use [109]. Cultivation of staple crops using agricultural wastes (crop residues, and animal manure (if there is any)) is beyond the reach of refugee farmers, due to competing demands on available residues, and lack of immediate benefits $[110,111]$. Hence, it would be more productive to search for locally untapped waste to integrate into kitchen gardening as a way of improving the nutritional value of okra at low cost to refugees. Positive mineral responses have been reported for wide varieties of okra as a result of using human urine, charred biomass, faecal sludge and manure as fertilizing materials $[109,112$, 113]. For example, $P$ contents in okra leaves increased by $11-900 \%$ in response to human urine application at a rate of 10.000 L/ha [112]. Similarly, Adekiya et al. [109]conducted a field trial to evaluate the mineral composition and yield of okra under maize cob ash application. They revealed that maize cob ash-fertilized okra pod exhibited a $100 \%$ Fe increment over an unfertilized control. Aside from promoting okra cultivation using grey water and locally available organic waste streams in a refugee context, Tilahun [114] pointed out the need for identifying affordable and effective storage technology when production is in surplus.

\subsection{Contribution to mineral dietary allowance}

With reference to $68 \mathrm{~g}$ (low-end consumption probability) fresh okra consumption for PLW, the estimated percentage contributions to Als were comparable for $\mathrm{K}$ and $\mathrm{Ca}$; a contribution ranging from 6.3 to $7 \%$ for $\mathrm{K}$ to a contribution ranging from 8.6 to $12.9 \%$ for Ca. Strikingly, with a reference to $42 \mathrm{~g} \mathrm{FW}$, okra could support ${ }^{<} 20 \%$ of the Als for $\mathrm{K}$ and $\mathrm{Ca}$ across the four refugee settlements and camps during young age. Similarly, with similar portion (42 $\mathrm{g}$ for young children aged between 1 and 3 years), okra pods and okra-based sauces would contribute ${ }^{<} 20 \%$ of RDA for these minerals in SSA $[37,38]$. Similarly, low consumption of okra-based traditional sauce in Cameroon by PLW and young children would meet ${ }^{<} 10 \% \mathrm{Al}$ for $\mathrm{K}$ and $\mathrm{Ca}$ [94]. Likewise, Ca-dense okra pod accessions (OPA\#3 and OPA\#6) would contribute only $4.2 \%$ of Al for Ca from 68 $\mathrm{g}$ fresh weight fruit consumption during pregnancy and lactation [34]. Yet, for young children aged between 1 and 3 years, it is worth to note that a $42 \mathrm{~g}$ serving portion of okra and/or okra-based traditional sauces could provide to the $\mathrm{Al}$ for $\mathrm{Ca}$ exceeding several-folds the percentage contributions that would be obtained from the consumption of various cereal-based foods in SSA [36-38, 89, 115]. Regarding $\mathrm{P}$ and $\mathrm{Mg}, 68 \mathrm{~g}$ Ethiopian okra (low-end consumption probability for PLW) has proved to be significant, potentially contributing $\geq 20 \%$ of their corresponding RDA values. Asimilar portion of Ugandan okra $(68 \mathrm{~g})$ is capable of contributing $8.5 \%$ and $18.4 \%$ of RDA for $\mathrm{P}$ and $\mathrm{Mg}$, respectively, during pregnancy.

For PLW, very high mineral contributions from okra pod consumption (high-end consumption probability) could be for $\mathrm{Mn}$ and the intakes would fall between 20.4 and 106\% Al (Table 2). At high-end consumption probability, similar contributions to $\mathrm{Al}$ (adequate intake) for Mn ranging from 11.3 to $80.6 \%$ could be obtained from studies in SSA $[30,37,87]$. Of interest in the refugee context is that $\mathrm{Fe} / \mathrm{Zn}$-dense plant foods could improve the nutritional status and health of young children and PLW because meat/poultry is the least consumed food group by refugees. Unfortunately, at low-end consumption probability, we observed relatively low levels of $\mathrm{Fe}$ in okra pods collected from the two refugee camps in Ethiopia. Despite low dietary contribution of Ethiopian okra to the RDA for Fe, less than $15 \%$ for young children and pregnant women, 
this still may have some positive nutritional implications given the huge prevalence of Fe deficiency during pregnancy in SSA particularly in a refugee setting. For example, in 2008 , anemia was the cause for $55 \%$ of maternal deaths in Daddab refugee camp in Kenya [116] and continues to exert maternal mortality in humanitarian crisis [117]. Likewise, Andresen et al. [118] found high overall prevalence of anemia among South Sudanese children aged between 6 and 59 months in Kule (51.9\%) and Tierkidi (46.2\%) refugee camps in Ethiopia, a value slightly higher than the demonstrated prevalence was obtained for South Sudanese children of similar ages residing in Pugnido refugee camp in Gambella region, Ethiopia [119]. According to Oboth et al. [120], among refugee children between the ages of 6 and 59 months residing in one of the largest refugee settlements in Uganda the overall prevalence of anemia was $64.9 \%$, higher in children with dual co-infection compared to single parasitic infection. Similarly, for children residing in Kebribeyah refugee camp in eastern Ethiopia, the overall prevalence of anemia was $52.4 \%$ [121]. Being anemic in young age, whether it is from iron deficiency, or parasitic infections, can have negative health consequences in both the short and long runs [118-120]. In another cross-sectional study in children residing in Kakuma refugee settlement in northern Kenya, the overall prevalence of anemia ranged between 44 and $77.1 \%$ [122]. On the other hand, Gemede et al. [34] revealed that there are some accessions with high Fe contents among locally cultivated varieties in western Ethiopia. Some of these accessions, OPA\#3, OPA\#5 and OPA\#6, could meet 48-137\% RDA for Fe during lactation for women aged between 19 and 30 years. Similarly, higher Fe intakes could be observed from the consumption of okra pods and sauces in West Africa [37, 100, 103]. In contrast, okra and okra-based sauces are capable of supplying only 1.4-6.2\% RDA for Fe during pregnancy [30, 38, 89, 94]. Regarding Zn, PLW taking $68 \mathrm{~g}$ of Ugandan okra and young children taking $17 \mathrm{~g}$ have proved to be a low contributor to $\mathrm{Zn}$, contributing $3 \%$ of its corresponding RDA value [76]. This is in agreement with several intake estimates made from composition data in SSA [30, 38, 87, $103,105]$. However, okra constitutes an excellent source of $\mathrm{Cu}$ in the diets of refugees in East Africa, potentially contributing to $9.8-48 \%$ for PLW and $9.4-35.1 \%$ for young children aged between 1 and 3 years, respectively.

In a refugee context, limited financial resources resulted in a decrease in the consumption of purchased fruits and vegetables [7]. Many studies have dealt with the impact of kitchen gardening on food security in a humanitarian setting [21, 123-126] but gardening programs have often been overlooked from a nutritional standpoint. Only recently, Adam-Bradford et al. [127] made an extensive review of emerging case studies concerning stabilization agriculture in complex emergencies. However, their focus was solely on the nexus among agriculture, food security and conflict. If properly designed, kitchen gardening programs would improve food as well as nutrition securities in a refugee setting.

In our study, mineral intakes associated with okra consumption was the main issue. The consumption of traditional okra-based sauces was previously shown to be relatively poor in terms of minerals in SSA $[86,94,105]$. The similarity in potential mineral supply (low intakes) from okra consumption between social settings (refugee vs. host) in SSA could be explained by the fact that the genetic potentials of okra remain poorly exploited via conventional breeding programs. On the other hand, specific genotypes from other territories could play a positive role on mineral intakes. For example, a genotype from Greece would have been observed to supply as much as $100 \%$ RDA for several minerals from the consumption of $100 \mathrm{~g}$ fresh okra [85]. These genotypes are notably excellent sources of the minerals that were the most deprived in samples from refugee settlements and camps in East Africa. This highlighted the need for developing nutritionsensitive kitchen gardening programs through introducing improved seeds of culturally important crops in refugee settings. These programmes have the advantage of providing acceptable means of reducing malnutrition in a refugee context, whereby the mistrust and myths associated with nutrition interventions would be addressed without changing culturally accepted diets [128, 129].

\subsection{Comparison of ICP-MS and PXRF}

Recently, several studies have exploited the low-cost and rapidity of PXRF-based analysis for profiling of minerals in accessions of various staples crops from biofortification breeding programs $[41,130,131]$. For PXRF measurements to be characterized quantitatively, $R^{2}$ should be $\geq 70 \%$ and RSD should not exceed $20 \%$ for all elements except $\mathrm{Cr}$, whose RSD should be less than $30 \%$ [78]. The RSD values in this study were less than $20 \%$ for all five of the elements with the exception of Fe. Calcium was at the very near threshold of achieving quantitative status. Fortunately, the contents of $\mathrm{Zn}$ and $\mathrm{Mn}$ in dried okra samples from the two geographic locations could be explained definitively $[45,78]$ with very strong correlations between PXRF and ICP-MS results. This is in agreement with several other works regarding quantitative and definitive evaluation of minerals in food and environmental samples using PXRF $[50,132]$. For example, Rouillon and Taylor [133] and Sosa et al. [42] achieved definitive level data for the same range of minerals studied in the present study.

In the present study, $\mathrm{K}$ and Fe could only be explained qualitatively using PXRF. In our previous work, relatively poor agreement between ICP-MS and PXRF measurements 
in terms of output concentrations for injera (a traditional Ethiopian flat bread) samples had been largely ascribed to the use of distinct sample sets and forms (fragments vs. powder) [33]. According to Tian et al. [134], minimum physical and mechanical preparation of soil samples resulted in poor PXRF performance. Despite some nonuniformity in agreement between PXRF and ICP-MS measurements for macro-minerals, it is worth noting that the most important micromineral ( $\mathrm{Zn}$ ) has been accurately determined by PXRF in this study. The excellent agreement for both $\mathrm{Zn}$ and Mn between ICP-MS and PXRF measurements could be partly attributed to the minimal interference effects associated with the very low levels of the analytes in question $[45,135]$. This study demonstrated that PXRF could be effectively employed for select mineral determination in culturally important orphan crop with a significant reduction in cost and time required for routine chemical analysis. This indicates the applicability of PXRF for a wide range of agricultural, human and animal nutrition, and environmental science contexts in SSA.

\section{Conclusion}

The contents of minerals in okra samples originating from four refugee settlements and camps in East Africa were determined by ICP-MS and PXRF. The PXRF employed in the present study avoided lengthy, time consuming, expensive and ecologically unfriendly sample pre-treatment steps. Moreover, there are few reports about multielement characterization of SSA orphan crops using PXRF. Thus, micro-mineral characterization of popular orphan crops accessions using PXRF seems worthwhile for biofortification programs in the region and beyond. Okra grown in refugee camps in Ethiopia was elevated relative to Ugandan okra in $\mathrm{P}, \mathrm{Mg}, \mathrm{Zn}, \mathrm{Mn}$ and $\mathrm{Cu}$ contents which could be associated to environmental conditions and genotypes grown. The study has also confirmed that local genotypes of okra could contribute little to the RDAs for minerals at certain life stages and low-end consumption probability, with the exception of $\mathrm{Mg}, \mathrm{Ca}, \mathrm{Mn}$ and $\mathrm{Cu}$. The results presented in this study are of great value for nutritional advice in a refugee context. Other micronutrients which are of public health concern in SSA, particularly in a refugee setting, should also be explored.

From a policy perspective, knowing these initial results demonstrate that even under agriculturally challenging conditions, it is possible to grow a crop that provides important nutritional diversity in a culturally familiar and acceptable way. Overall, efforts should be directed towards incorporating nutrient-dense cultivation of culturally important crops into kitchen gardening programs in a humanitarian setting. For this to happen there is need to support the refugees with technical skills that will contribute towards enhancing soil fertility and access to irrigation through recovering and reusing organic waste and grey wastewater. This way okra or any other orphan crop production will be of enhanced nutritional value and its availability ensured during the dry spells in these marginal areas. In addition, nutritional education is also crucial for nutritionally deprived people in a refugee context including the communities that are currently not engaged in growing crops.

Acknowledgements The gender researcher (RM) from Pennsylvania State University is provided by the United States Department of Agriculture (USDA) National Institute of Food and Agriculture and Hatch Appropriations under Project \#PEN04724 and Accession \#1020895. Technical and human support provided by CICT of Universidad de Jaén (UJA, MINECO, Junta de Andalucía, FEDER), and the Physics Department, Mount Allison University, is strongly acknowledged. We are grateful for Pay Drechsel for the thorough review. We are also grateful to Binyam Tesfaye, Befekadu Elfiyos, Dr. Clement Okia, Dr. Erik Francis Acanakwo and Florence Kandole for the support during sample collection.

Funding Baseline assessment was enabled by funding from Bundesministerium für wirtschaftliche Zusammenarbeit und Entwicklung (BMZ) (Federal Ministry for Economic Cooperation and Development), Germany and CGIAR Research Program on Water, Land and Ecosystems (WLE) under the project on Resource Recovery and Reuse (RRR) in refugee settlements in Africa. Partial funding was provided by a Discovery Grant awarded to DEBF (2018-03902) by the Natural Sciences and Engineering Research Council of Canada.

Availability of data and material Data are available upon reasonable request.

\section{Declarations}

Conflict of interest The authors declare no conflict of interest.

Code availability Data were analyzed using Statistical Package for Social Sciences (SPSS) version 23.

Open Access This article is licensed under a Creative Commons Attribution 4.0 International License, which permits use, sharing, adaptation, distribution and reproduction in any medium or format, as long as you give appropriate credit to the original author(s) and the source, provide a link to the Creative Commons licence, and indicate if changes were made. The images or other third party material in this article are included in the article's Creative Commons licence, unless indicated otherwise in a credit line to the material. If material is not included in the article's Creative Commons licence and your intended use is not permitted by statutory regulation or exceeds the permitted use, you will need to obtain permission directly from the copyright holder. To view a copy of this licence, visit http://creativecommons. org/licenses/by/4.0/. 


\section{References}

1. UNHCR (2018) South Sudan Refugee Crisis. https://www.unref ugees.org/emergencies/south-sudan/?. Accessed 7 Mar 2020

2. Atari DO, McKague K (2019) Using livelihoods to support primary health care for South Sudanese refugees in Kiryandongo, Uganda. S Sudan Med J 12(2):38-43

3. SIDA (2019) South Sudan crisis: Humanitarian Crisis Analysis, Draft 2019-12-14, 2019. https://www.sida.se/globalassets/ sida/eng/how-we-work/humanitarian-aid/hca-2019/hcasouth-sudan-crisis-2019.pdf. Accessed 7 Mar 2020

4. Rubenstein BL, Stark L (2017) The impact of humanitarian emergencies on the prevalence of violence against children: an evidence-based ecological framework. Psychol Health Med 22(sup1):58-66. https://doi.org/10.1080/13548506.2016.12719 49

5. Lockyer S, White A, Buttriss JL (2018) Biofortified crops for tackling micronutrient deficiencies-what impact are these having in developing countries and could they be of relevance within Europe? Nutr Bull 43(4):319-357. https://doi.org/10.1111/nbu. 12347

6. Sciacca F, Allegra M, Licciardello S, Roccuzzo G, Torrisi B, Virzì N, Brambilla M, Romano E, Palumbo M (2018) Potential use of sicilian landraces in biofortification of modern durum wheat varieties: evaluation of caryopsis micronutrient concentrations. Cereal Res Commun 46(1):124-134. https://doi.org/10.1556/ 0806.45.2017.056

7. Ververs M, Muriithi JW, Burton A, Burton JW, Lawi AO (2019) Scurvy Outbreak among south sudanese adolescents and young men-Kakuma Refugee Camp, Kenya, 2017-2018. Morb Mortal Wkly Rep 68(3):72-75. https://doi.org/10.15585/mmwr. $\mathrm{mm} 6803 \mathrm{a} 4$

8. Prinzo ZW, De Benoist B (2002) Meeting the challenges of micronutrient deficiencies in emergency-affected populations. Proc Nutr Soc 61(2):251-257. https://doi.org/10.1079/PNS20 02151

9. Shenkin A (2006) The key role of micronutrients. Clin Nutr 25(1):1-13. https://doi.org/10.1016/j.clnu.2005.11.006

10. Dommisch H, Kuzmanova D, Jönsson D, Grant M, Chapple I (2018) Effect of micronutrient malnutrition on periodontal disease and periodontal therapy. Periodontology 78(1):129-153. https://doi.org/10.1111/prd.12233

11. WFP (2012) WFP nutrition policy. Executive Board Document, Policy Issues, Agenda Item 5. Rome, Italy

12. Webb P, Boyd E, de Pee S, Lenters L, Bloem M, Schultink W (2014) Nutrition in emergencies: do we know what works? Food Policy 49:33-40. https://doi.org/10.1016/j.foodpol.2014. 03.016

13. Caulfield LE, Zavaleta N, Shankar AH, Merialdi M (1998) Potential contribution of maternal zinc supplementation during pregnancy to maternal and child survival. Am J Clin Nutr 68(2):499S-508S. https://doi.org/10.1093/ajen/68.2.499S

14. Zimmermann MB, Köhrle J (2002) The impact of iron and selenium deficiencies on iodine and thyroid metabolism: biochemistry and relevance to public health. Thyroid 12(10):867-878. https://doi.org/10.1089/105072502761016494

15. Spencer BH, Vanderlelie JJ, Perkins AV (2015) Essentiality of trace element micronutrition in human pregnancy: a systematic review. J Preg Child Health 2(157):1-7. https://doi.org/10. 4172/2376-127X.1000157

16. Van Jaarsveld $P$, Faber $M$, Van Heerden I, Wenhold F, van Rensburg WJ, Van Averbeke W (2014) Nutrient content of eight African leafy vegetables and their potential contribution to dietary reference intakes. J Food Compost Anal 33(1):77-84. https:// doi.org/10.1016/j.jfca.2013.11.003
17. Fungo R, Muyonga J, Kabahenda M, Kaaya A, Okia CA, Donn $P$, Mathurin T, Tchingsabe O, Tiegehungo JC, Loo J, Snook L (2016) Contribution of forest foods to dietary intake and their association with household food insecurity: a cross-sectional study in women from rural Cameroon. Public Health Nutr 19(17):31853196. https://doi.org/10.1017/S1368980016001324

18. Chivenge $P$, Mabhaudhi T, Modi AT, Mafongoya P (2015) The potential role of neglected and underutilised crop species as future crops under water scarce conditions in Sub-Saharan Africa. Int J Environ Res Public Health 12(6):5685-5711. https:// doi.org/10.3390/ijerph120605685

19. CGIAR-WLE (2019, October 24) New project offers circular economy solutions for refugee and host communities in East Africa. https://wle.cgiar.org/new-project-offers-circular-econo my-solutions-refugee-and-host-communities-east-africa. Accessed on 24 Oct 2019

20. Zeven AC (1998) Landraces: a review of definitions and classifications. Euphytica 104:127-139. https://doi.org/10.1023/A: 1018683119237

21. Adam-Bradford A, Hoekstra F, Van Veenhuizen R (2009) Linking relief, rehabilitation and development: a role for urban agriculture. Urban Agric Mag 21:3-10

22. DRC (2019, May 24) Innovative farming boosts food production for refugees in Uganda. https://drc.ngo/what-we-do/stori es-from-the-field/innovative-farming-boosts-food-productionfor-refugees-in-uganda. Accessed on 07 Mar 2020

23. AOCC (2018) African Orphan Crops Consortium. https://www. africanorphancrops.org/. Accessed on 2 Mar 2020

24. Leonardo E, Dorward P, Garforth C, Sutcliffe C, Van Hulst F (2020) Conflict-induced displacement as a catalyst for agricultural innovation: findings from South Sudan. Land Use Policy 90:104272. https://doi.org/10.1016/j.landusepol.2019.104272

25. Betts A, Omata N, Rodgers C, Sterck O, Stierna M (2019) The Kalobeyei model: towards self-reliance for refugees? RSC, Oxford

26. Hengsdijk $H$, Hermelink $M$, van Reuler $H$, Ndambi OA, Roefs MMI, Tichar T (2019) Back to office report of a visit to West Nile region in Uganda. Wageningen Research

27. Willis MS, Buck JS (2007) From Sudan to Nebraska: Dinka and Nuer refugee diet dilemmas. J Nutr Educ Behav 39(5):273-280. https://doi.org/10.1016/j.jneb.2006.10.005

28. Njenga $M$, Gebrezgabher $S$, Mendum R, Adam-Bradford A, Woldetsadik D, Okia C (2020) Circular economy solutions for resilient refugee and host communities in East Africa. Project brief series No. 1. IWMI, Colombo, Sri Lanka. https://hdl.handle. net/10568/109549

29. Effiong GS, Ogban PI, Ibia TO, Adam AA (2009) Evaluation of nutrient supplying potentials of fluted pumpkin (Telfairia occidentalis, Hook, F.) and Okra (Abelmoschus esculentus) (L.) Moench. AJPS 2(3):209-214

30. Kehinde MO, Olumide OF, Ramat MF (2015) Adequacy of mineral contents of raw and plain sticky sauce of common and bush okra. Ital J Food Sci 27(4):513-520

31. Oka RC (2014) Coping with the refugee wait: the role of consumption, normalcy, and dignity in refugee lives at Kakuma Refugee Camp, Kenya. Am Anthropol 116(1):23-37. https://doi. org/10.1111/aman.12076

32. Stadlmayr B, Charrondière UR, Burlingame B (2013) Development of a regional food composition table for West Africa. Food Chem 140(3):443-446. https://doi.org/10.1016/j.foodchem. 2012.09.107

33. Woldetsadik D, Llorent-Martínez EJ, Ortega-Barrales $P$, Haile A, Hailu H, Madani N, Warner NS, Fleming DE (2020) Contents of metal (loid) $s$ in a Traditional Ethiopian Flat Bread (Injera), dietary intake, and health risk assessment in Addis Ababa, 
Ethiopia. Biol Trace Elem Res 198(2):732-743. https://doi.org/ 10.1007/s12011-020-02099-7

34. Gemede HF, Haki GD, Beyene F, Woldegiorgis AZ, Rakshit SK (2016) Proximate, mineral, and antinutrient compositions of indigenous Okra (Abelmoschus esculentus) pod accessions: implications for mineral bioavailability. Food Sci Nutr 4(2):223233. https://doi.org/10.1002/fsn3.282

35. Kibatu G, Chacha R, Kiende R (2017) Determination of major, minor and trace elements in Tef using portable total $x$-ray fluorescence (TXRF) spectrometer. EC Nutr 9(1):51-59

36. Nyachoti S, Adebayo S, Godebo TR (2021) Elemental composition of teff (a gluten-free grain), maize and wheat: Staple crops in the Main Ethiopian Rift Valley. J Food Compost Anal 100:103660. https://doi.org/10.1016/j.jfca.2020.103660

37. Mitchikpe CE (2007) Towards a food-based approach to improve iron and zinc status of rural Beninese children: enhancing mineral bioavailability from sorghum-based food, PhD thesis, Wageningen University, p 81

38. Kamga RT, Kouamé $C$, Atangana AR, Chagomoka T, Ndango R (2013) Nutritional evaluation of five African indigenous vegetables. J Hort Res 21(1):99-106. https://doi.org/10.2478/ johr-2013-0014

39. Okello J, Okullo JB, Eilu G, Nyeko P, Obua J (2017) Mineral composition of Tamarindus indica LINN (Tamarind) pulp and seeds from different agro-ecological zones of Uganda. Food Sci Nutr 5(5):959-966. https://doi.org/10.1002/fsn3.490

40. Mottese AF, Naccari C, Vadalà R, Bua GD, Bartolomeo G, Rando R, Cicero N, Dugo G (2018) Traceability of Opuntia ficus-indica L. Miller by ICP-MS multi-element profile and chemometric approach. J Sci Food Agric 98(1):198-204. https://doi.org/10. 1002/jsfa.8456

41. Guild GE, Paltridge NG, Andersson MS, Stangoulis JC (2017) An energy-dispersive $\mathrm{X}$-ray fluorescence method for analysing Fe and $\mathrm{Zn}$ in common bean, maize and cowpea biofortification programs. Plant Soil 419(1-2):457-466. https://doi.org/10. 1007/s11104-017-3352-4

42. Sosa P, Guild G, Burgos G, Bonierbale M, Zum Felde T (2018) Potential and application of X-ray fluorescence spectrometry to estimate iron and zinc concentration in potato tubers. J Food Compost Anal 70:22-27. https://doi.org/10.1016/j.jfca.2018.03. 004

43. Sapkota Y, McDonald LM, Griggs TC, Basden TJ, Drake BL (2019) Portable X-ray fluorescence spectroscopy for rapid and costeffective determination of elemental composition of ground forage. Front Plant Sci 10:317. https://doi.org/10.3389/fpls. 2019.00317

44. Piorek S (1997) Field-portable X-ray fluorescence spectrometry: past, present, and future. Field Anal Chem Technol 1(6):317329. https://doi.org/10.1007/978-94-009-1473-5_76

45. Kilbride C, Poole J, Hutchings TR (2006) A comparison of $\mathrm{Cu}$, $\mathrm{Pb}, \mathrm{As}, \mathrm{Cd}, \mathrm{Zn}, \mathrm{Fe}, \mathrm{Ni}$ and $\mathrm{Mn}$ determined by acid extraction/ ICP-OES and ex situ field portable $X$-ray fluorescence analyses. Environ Pollut 143(1):16-23. https://doi.org/10.1016/j.envpol. 2005.11.013

46. Daly K, Fenelon A (2018) Application of energy dispersive $\mathrm{X}$-ray fluorescence spectrometry to the determination of copper, manganese, zinc, and sulfur in grass (Lolium perenne) in grazed agricultural systems. Appl Spectrosc 72(11):1661-1673. https://doi.org/10.1177/0003702818787165

47. Lynch SC, Locock AJ, Duke MJM, Weber AW (2016) Evaluating the applicability of portable-XRF for the characterization of Hokkaido Obsidian sources: a comparison with INAA, ICP-MS and EPMA. J Radioanal Nucl Chem 309(1):257-265. https://doi. org/10.1007/s10967-016-4766-9

48. Herreros-Chavez L, Cervera ML, Morales-Rubio A (2019) Direct determination by portable ED-XRF of mineral profile in cocoa powder samples. Food Chem 278:373-379. https://doi.org/10. 1016/j.foodchem.2018.11.065

49. Weindorf DC, Bakr N, Zhu Y (2014) Advances in portable X-ray fluorescence (PXRF) for environmental, pedological, and agronomic applications. In: Advances in agronomy, vol 128. Academic Press, pp 1-45

50. McLaren TI, Guppy CN, Tighe MK (2012) A rapid and nondestructive plant nutrient analysis using portable X-ray fluorescence. Soil Sci Soc Am J 76(4):1446-1453. https://doi.org/ $10.2136 /$ sssaj2011.0355

51. UNHCR (2020) Camp Profile Gambella- Kule refugee camp. https://data2.unhcr.org/en/documents/download/73871. Accessed 9 Mar 2020

52. UNHCR (2020) Camp Profile Gambella- Tierkidi refugee camp. https://data2.unhcr.org/en/documents/details/73872. Accessed 9 Mar 2020

53. UNHCR (2020) South Sudan Situation: Refugee population in Gambella region. https://reliefweb.int/sites/reliefweb.int/ files/resources/South\%20Sudan\%20Situation $\% 20 \% 20$ Ref ugee\%20population\%20in\%20Gambella\%20region\%20as\% 20of\%2031\%20May\%202020.pdf. Accessed 8 Oct 2020

54. Kottek M, Grieser J, Beck C, Rudolf B, Rubel F (2006) World map of the Köppen-Geiger climate classification updated. Meteorol Z 15(3):259-263. https:// doi.org/10.1127/09412948/2006/0130

55. Climate data (2021) Climate Gambella, Ethiopia. https://www. weatherbase.com/weather/weather-summary.php3? $s=60190$ $8 \&$ cityname $=$ Gambela $\% 2 C+$ Gambela $\% 2 C+$ Ethiopia\&units $=$. Accessed on 8 Nov 2021

56. Rozanov BG, Chelyadnik PT (1983) Soils of the Gambela region in Ethiopia. Moscow University soil science bulletin (USA)

57. Rybalov LB (1990) Comparative characteristics of soil macrofauna of some tropical savannah communities in Equatorial Africa: preliminary results. Trop Zool 3(1):1-11. https://doi.org/ 10.1080/03946975.1990.10539445

58. UNHCR (2020) Uganda Fact sheet. https://data2.unhcr.org/en/ documents/details/74400. Accessed 9 Mar 2020

59. UNHCR (2020) Refugees and Asylum-Seekers in Uganda Uganda Refugee Response. https://reliefweb.int/map/uganda/ refugees-and-asylum-seekers-uganda-30-september-2020. Accessed 8 Oct 2020

60. Grosrenaud E, Okia CA, Adam-Bradford A, Trenchard L (2021) Agroforestry: challenges and opportunities in Rhino Camp and Imvepi refugee settlements of Arua District, Northern Uganda. Sustainability 13(4):2134. https://doi.org/10.3390/su13042134

61. Minai JO (2015) Assessing the spatial variability of soils in Uganda. MSc thesis, Purdue University, West Lafayette, Indiana, USA

62. UNHCR Ethiopia (2020) Ethiopia operation Tierkidi-Camp Profile. https://reliefweb.int/report/ethiopia/ethiopia-operationtierkidi-camp-profile-november-2020. Accessed 7 Dec 2020

63. UNHCR (2020) Ethiopia: Camp Profile Gambella- Kule Refugee Camp. https://reliefweb.int/report/ethiopia/ethiopia-campprofile-gambella-kule-refugee-camp-may-2020. Accessed 7 Dec 2020

64. UNHCR (2020) Uganda-Refugee Statistics September 2020Rhino. https://reliefweb.int/report/uganda/uganda-refugeestatistics-september-2020-rhino. Accessed 7 Dec 2020

65. UNHCR (2020) Uganda-Refugee Statistics July 2020-Imvepi. https://reliefweb.int/report/uganda/uganda-refugee-stati stics-july-2020-imvepi. Accessed 7 Dec 2020

66. Wood LJ, Sharpless KE, Pichon M, Porter BJ, Yen JH (2011) Characterization of three berry standard reference materials for nutrients. J Agric Food Chem 59:7246-7252. https://doi.org/ $10.1021 / \mathrm{jf} 200883 \mathrm{e}$ 
67. Llorent-Martínez EJ, Fernández-de Córdova ML, Ortega-Barrales P, Ruiz-Medina A (2013) Characterization and comparison of the chemical composition of exotic superfoods. Microchem J 110:444-451. https://doi.org/10.1016/j.microc.2013.05.016

68. Fleming DE, Crook SL, Evans CT (2019) Assessing zinc from a nail clipping using mono-energetic portable $\mathrm{X}$-ray fluorescence. Appl Radiat Isot 145:170-175. https://doi.org/10.1016/j. apradiso.2018.12.033

69. Relief International (2017) Baseline Survey Report For Conducting A Market Assessment To Investigate The Implementation Gaps In Sustainable And High Demand Agricultural Commodities For Batil And Doro Refugee Camps In Maban, Upper Nile, South Sudan. https://fscluster.org/sites/default/files/docum ents/relief_international_market_assessment_maban_march_ 2017 external.pdf. Accessed Dec 112020

70. Pollard C, Miller M, Woodman RJ, Meng R, Binns C (2009) Changes in knowledge, beliefs, and behaviors related to fruit and vegetable consumption among Western Australian adults from 1995 to 2004. Am J Public Health 99(2):355-361

71. Grimm KA, Kim SA, Yaroch AL, Scanlon KS (2014) Fruit and vegetable intake during infancy and early childhood. Pediatrics 134(Supplement 1):S63-S69. https://doi.org/10.1542/ peds.2014-0646K

72. Adedeji AA, Gachovska TK, Ngadi MO, Raghavan GSV (2008) Effect of pre-treatments on drying characteristics of okra. Dry Technol 26(10):1251-1256. https://doi.org/10.1080/07373 930802307209

73. Xuan G, Gao C, Shao Y, Wang X, Wang Y, Wang K (2021) Maturity determination at harvest and spatial assessment of moisture content in okra using Vis-NIR hyperspectral imaging. Postharvest Biol Technol 180:111597. https://doi.org/10. 1016/j.postharvbio.2021.111597

74. WHO (2003) Diet, nutrition and the prevention of chronic diseases. Report of a Joint 650 FAO/WHO Expert Consultation. WHO Technical Report Series No. 916. World Health Organization, Geneva, 651 Switzerland

75. IOM (1997) Food and Nutrition Board. Dietary reference intakes for calcium, phosphorus, magnesium, vitamin D, and fluoride. National Academy Press, Washington, DC

76. IOM (2001) Food and Nutrition Board. Dietary Reference Intakes for Vitamin A, Vitamin K, Arsenic, Boron, Chromium, Copper, lodine, Iron, Manganese, Molybdenum, Nickel, Silicon, Vanadium, and Zinc. National Academy Press, Washington, DC

77. IOM (2005) Dietary reference intakes for water, potassium, sodium, chloride, and sulfate. National Academy Press, Washington, DC

78. USEPA (1998) Environmental technology verification report. Field portable X-ray fluorescence analyzer. Metorex X-MET 920-P and 940, EPA/600/R-97/146. USEPA

79. Cakmak I, Pfeiffer WH, McClafferty B (2010) Biofortification of durum wheat with zinc and iron. Cereal Chem 87(1):10-20. https://doi.org/10.1094/CCHEM-87-1-0010

80. Gernand AD, Schulze KJ, Stewart CP, West KP, Christian P (2016) Micronutrient deficiencies in pregnancy worldwide: health effects and prevention. Nat Rev Endocrinol 12(5):274-289. https://doi.org/10.1038/nrendo.2016.37

81. Vohr BR, Davis EP, Wanke CA, Krebs NF (2017) Neurodevelopment: the impact of nutrition and inflammation during preconception and pregnancy in low-resource settings. Pediatrics 139(Supplement 1):S38-S49. https://doi.org/10.1542/peds. 2016-2828F

82. Muthayya S, Rah JH, Sugimoto JD, Roos FF, Kraemer K, Black RE (2013) The global hidden hunger indices and maps: an advocacy tool for action. PLoS ONE 8(6):e67860. https://doi.org/10. 1371/journal.pone.0067860
83. Hendre PS, Muthemba S, Kariba R, Muchugi A, Fu Y, Chang $Y$, Song B, Liu H, Liu M, Liao X, Sahu SK (2019) African orphan crops consortium (AOCC): status of developing genomic resources for African orphan crops. Planta 250:989-1003. https://doi.org/10.1007/s00425-019-03156-9

84. Baldermann S, Blagojević L, Frede K, Klopsch R, Neugart S, Neumann A, Ngwene B, Norkeweit J, Schröter D, Schröter A, Schweigert FJ (2016) Are neglected plants the food for the future? CRC Crit Rev Plant Sci 35(2):106-119. https://doi.org/10.1080/ 07352689.2016.1201399

85. Petropoulos S, Fernandes Â, Barros L, Ferreira IC (2018) Chemical composition, nutritional value and antioxidant properties of Mediterranean okra genotypes in relation to harvest stage. Food Chem 242:466-474. https://doi.org/10.1016/j.foodchem. 2017.09.082

86. Ferguson EL, Gibson RS, Weaver SD, Heywood P, Heywood A, Yaman C (1989) The mineral content of commonly consumed Malawian and Papua New Guinean foods. J Food Compost Anal 2(3):260-272. https://doi.org/10.1016/0889-1575(89)90023-9

87. Ponka R, Fokou E, Kansci G, Beaucher E, Piot M, Leonil J, Gaucheron $F$ (2014) Recipes, proximate and mineral composition of some traditional sauces consumed in the far North Region of Cameroon. Int Food Res J 21(4):1589-1596

88. Del Valle HB, Yaktine AL, Taylor CL, Ross AC (2011) Dietary reference intakes for calcium and vitamin D. eds., National Academies Press

89. Chitsiku IC (1989) Nutritive Value of Foods of Zimbabwe. University of Zimbabwe Publications, Harare, Zimbabwe

90. Petropoulos S, Fernandes Â, Barros L, Ciric A, Sokovic M, Ferreira IC (2017) The chemical composition, nutritional value and antimicrobial properties of Abelmoschus esculentus seeds. Food Funct 8(12):4733-4743. https://doi.org/10.1039/C7FO01446E

91. El-Nahry FI, El-Ghorab MI, Younes R (1978) Nutritive value of local varieties of fresh and sundried okra (hibiscus esculentus) pods and seeds. Qualitas Plantarum 28(3):227-231. https://doi. org/10.1007/BF01093952

92. Alake CO (2020) Genetic variability and diversity in okra landraces using agromorphological traits and seed elemental minerals. Int J Veg Sci 26(2):127-149. https://doi.org/10.1080/ 19315260.2019.1610926

93. Sumczynski D, Koubová E, Šenkárová L, Orsavová J (2018) Rice flakes produced from commercial wild rice: chemical compositions, vitamin B compounds, mineral and trace element contents and their dietary intake evaluation. Food Chem 264:386-392. https://doi.org/10.1016/j.foodchem.2018.05.061

94. Kana Sop MM, Gouado I, Mofor CT, Smriga M, Fotso M, Ekoe T (2008) Mineral content in some Cameroonian household foods eaten in Douala. Afr J Biotechnol 7(17):3085-3091

95. Ayaz FA, Glew RH, Millson M, Huang HS, Chuang LT, Sanz C, Hayırlıglu-Ayaz S (2006) Nutrient contents of kale (Brassica oleraceae L. var. acephala DC.). Food Chem 96(4):572-579. https://doi.org/10.1016/j.foodchem.2005.03.011

96. Orech FO, Christensen DL, Larsen T, Friis H, Aagaard-Hansen J, Estambale BA (2007) Mineral content of traditional leafy vegetables from western Kenya. Int J Food Sci Nutr 58(8):595-602. https://doi.org/10.1080/09637480701350288

97. Odhav B, Beekrum S, Akula US, Baijnath H (2007) Preliminary assessment of nutritional value of traditional leafy vegetables in KwaZulu-Natal, South Africa. J Food Compost Anal 20(5):430-435. https://doi.org/10.1016/j.jfca.2006.04.015

98. Schönfeldt HC, Pretorius B (2011) The nutrient content of five traditional South African dark green leafy vegetables-A preliminary study. J Food Compost Anal 24(8):1141-1146

99. Kruger J, Mongwaketse T, Faber M, Van der Hoeven M, Smuts CM (2015) Potential contribution of African green leafy 
vegetables and maize porridge composite meals to iron and zinc nutrition. Nutrition 31(9):1117-1123

100. Avallone $S$, Brault $S$, Mouquet $C$, Trèche $S$ (2007) Home-processing of the dishes constituting the main sources of micronutrients in the diet of preschool children in rural Burkina Faso. Int J Food Sci Nutr 58:108-115. https://doi.org/10.1080/0963748060 1143320

101. Omoniyi SA, Idowu MA, Francis PN, Adeola AA (2020) Nutrient Composition and functional properties of okra seed flour and some quality attributes of its soups. J Culin Sci Technol. https:// doi.org/10.1080/15428052.2020.1759169

102. Salgueiro MJ, Zubillaga M, Lysionek A, Cremaschi G, Goldman CG, Caro R, De Paoli T, Hager A, Weill R, Boccio J (2000) Zinc status and immune system relationship. Biol Trace Elem Res 76(3):193-205. https://doi.org/10.1385/BTER:76:3:193

103. Avallone S, Tiemtore TWE, Mouquet-Rivier C, Trèche S (2008) Nutritional value of six multi-ingredient sauces from Burkina Faso. J Food Compost Anal 21(7):553-558. https://doi.org/10. 1016/j.jfca.2008.04.012

104. Ahiakpa JK, Amoatey HM, Amenorpe G, Apatey J, Ayeh EA, Agbemavor WSK (2014) Mucilage content of 21 accessions of Okra (Abelmoschus spp L.). Sci Agric 2(2):96-101. https://doi. org/10.15192/pscp.sa.2014.2.2.96101

105. Ponka R, Fokou E, Fotso M, Tchouanguep FM, Leke R, Souopgui J, Bih MA (2006) Composition of dishes consumed in Cameroon. Int J Food Sci Technol 41(4):361-365. https:// doi.org/10.1111/j.1365-2621.2005.01072.x

106. Arapitsas P (2008) Identification and quantification of polyphenolic compounds from okra seeds and skins. Food Chem 110(4):1041-1045. https://doi.org/10.1016/j.foodchem.2008. 03.014

107. Xu K, Guo M, Roman L, Pico J, Martinez MM (2020) Okra seed and seedless pod: comparative study of their phenolics and carbohydrate fractions and their impact on bread-making. Food Chem 317:126387. https://doi.org/10.1016/j.foodchem. 2020.126387

108. Makhadmeh IM, Ereifej KI (2004) Geometric characteristics and chemical composition of okra (Hibiscus esculentus L.) grown under semi-arid conditions. Int J Food Prop 7(1):8390. https://doi.org/10.1081/JFP-120022983

109. Adekiya AO, Aboyeji CM, Dunsin O, Adebiyi OV, Oyinlola OT (2018) Effect of urea fertilizer and maize cob ash on soil chemical properties, growth, yield, and mineral composition of okra, Abelmoschus esculentus (L.) Moench. J Hort Res 26(1):67-76. https://doi.org/10.2478/johr-2018-0008

110. Vanlauwe B, Wendt J, Giller KE, Corbeels M, Gerard B, Nolte $C$ (2014) A fourth principle is required to define conservation agriculture in sub-Saharan Africa: the appropriate use of fertilizer to enhance crop productivity. Field Crops Res 155:10-13. https://doi.org/10.1016/j.fcr.2013.10.002

111. Nigussie A, Kuyper TW, de Neergaard A (2015) Agricultural waste utilisation strategies and demand for urban waste compost: evidence from smallholder farmers in Ethiopia. Waste Manag 44:82-93. https://doi.org/10.1016/j.wasman. 2015.07.038

112. Akpan-Idiok AU, Udo IA, Braide EI (2012) The use of human urine as an organic fertilizer in the production of okra (Abelmoschus esculentus) in South Eastern Nigeria. Resour Conserv Recycl 62:14-20. https://doi.org/10.1016/j.resconrec.2012.02. 003

113. Adekiya AO, Agbede TM, Aboyeji CM, Dunsin O (2017) Response of okra (Abelmoschus esculentus (L.) Moench) and soil properties to different mulch materials in different cropping seasons. Sci Hortic 217:209-216. https://doi.org/10. 1016/j.scienta.2017.01.053
114. Tilahun SW (2010) Feasibility and economic evaluation of lowcost evaporative cooling system in fruit and vegetables storage. Afr J Food Agric Nutr Dev 10(8)

115. Dimaria SA, Schwartz H, Icard-Vernière C, Picq C, Zagre NM, Mouquet-Rivier C (2018) Adequacy of some locally produced complementary foods marketed in Benin, Burkina faso, Ghana, and Senegal. Nutrients 10(6):785. https://doi.org/10.3390/ nu10060785

116. UNHCR (2010) Improving maternal care in Dadaab refugee camps, Kenya. www.unhcr.org/4c247d969.pdf

117. Kay A, Leidman E, Lopez V, Wilkinson C, Tondeur M, Bilukha O (2019) The burden of anaemia among displaced women and children in refugee settings worldwide, 2013-2016. BMJ Glob Health 4(6):e001837. https://doi.org/10.1136/ bmjgh-2019-001837

118. Andresen E, Bilukha OO, Menkir Z, Gayford M, Kavosa M, Wtsadik M, Maina G, Gose M, Nyagucha I, Shahpar C (2014) Malnutrition and elevated mortality among refugees from South Sudan-Ethiopia, June-July 2014. MMWR 63(32):700-701

119. Seal AJ, Creeke PI, Mirghani Z, Abdalla F, McBurney RP, Pratt LS, Brookes D, Ruth LJ, Marchand E (2005) Iron and vitamin A deficiency in long-term African refugees. J Nutr 135(4):808-813. https://doi.org/10.1093/jn/135.4.808

120. Oboth P, Gavamukulya Y, Barugahare BJ (2019) Prevalence and clinical outcomes of Plasmodium falciparum and intestinal parasitic infections among children in Kiryandongo refugee camp, mid-Western Uganda: a cross sectional study. BMC Infect Dis 19(1):1-8. https://doi.org/10.1186/s12879-019-3939-x

121. Jemal Y, Haidar J, Makau WK (2017) The magnitude and determinants of anaemia among refugee preschool children from the Kebribeyah refugee camp, Somali region, Ethiopia. South Afr J Clin Nutr 30(1):1-6. https://hdl.handle.net/10520/EJC6de7ffe0e

122. Style S, Tondeur M, Grijalva-Eternod C, Pringle J, Kassim I, Wilkinson C, Oman A, Dolan C, Spiegel P, Seal A (2017) Assessment of the effectiveness of a small quantity lipid-based nutrient supplement on reducing anaemia and stunting in refugee populations in the Horn of Africa: Secondary data analysis. PLoS ONE 12(6):e0177556. https://doi.org/10.1371/journal. pone. 0177556

123. Adam-Bradford A, Osman M (2009) Tsunami Aftermath: development of an indigenous home garden in Banda Aceh. Urban Agric Mag 21:29-30

124. Wtsadik M (2009) Enhancing household food security in refugee camps in Ethiopia. Urban Agric Mag 20:16-17

125. Mallett R, Slater R (2012) Growth and livelihoods in fragile and conflict-affected situations, vol 9. Working Paper

126. Millican J, Perkins C, Adam-Bradford A (2019) Gardening in displacement: the benefits of cultivating in crisis. J Refug Stud 32(3):351-371. https://doi.org/10.1093/jrs/fey033

127. Adam-Bradford A, El-Kahlout G, Byrne R, Wright J, Rahman M (2020) Stabilisation agriculture: reviewing an emerging concept with case studies from Afghanistan and Iraq. CAB Rev Perspect Agric Vet Sci Nutr Nat Resour 15(42). https://doi.org/ 10.1079/PAVSNNR202015042

128. Kodish S, Rah JH, Kraemer K, De Pee S, Gittelsohn J (2011) Understanding low usage of micronutrient powder in the Kakuma Refugee Camp, Kenya: findings from a qualitative study. Food Nutr Bull 32(3):292-303. https://doi.org/10.1177/ 156482651103200315

129. Mannion CA, Raffin-Bouchal S, Henshaw CJ (2014) Navigating a strange and complex environment: experiences of Sudanese refugee women using a new nutrition resource. Int J Womens Health 6:411-422. https://doi.org/10.2147/IJWH.S56256

130. Paltridge N, Milham P, Ortiz-Monasterio J, Velu G, Yasmin Z, Palmer L, Guild G, Stangoulis J (2012) Energy-dispersive X-ray 
fluorescence spectrometry as a tool for zinc, iron and selenium analysis in whole grain wheat. Plant Soil 361:261-269. https:// doi.org/10.1007/s11104-012-1423-0

131. Paltridge NG, Palmer LJ, Milham PJ, Guild GE, Stangoulis J (2012) Energy-dispersive X-ray fluorescence analysis of zinc and iron concentration in rice and pearl millet grain. Plant Soil 361:251-260. https://doi.org/10.1007/s11104-011-1104-4

132. Zhou S, Weindorf DC, Cheng Q, Yang B, Yuan Z, Chakraborty S (2020) Elemental assessment of vegetation via portable XRF: sample preparation and methodological considerations. Spectrochim Acta B 174:105999. https://doi.org/10.1016/j.sab.2020. 105999

133. Rouillon M, Taylor MP (2016) Can field portable X-ray fluorescence $(p X R F)$ produce high quality data for application in environmental contamination research? Environ Pollut 214:255-264. https://doi.org/10.1016/j.envpol.2016.03.055

134. Tian K, Huang B, Xing Z, Hu W (2018) In situ investigation of heavy metals at trace concentrations in greenhouse soils via portable X-ray fluorescence spectroscopy. Environ Sci Pollut Res 25(11):11011-11022. https://doi.org/10.1007/ s11356-018-1405-8

135. Schneider JF, Johnson D, Stoll N, Thurow K, Thurow K (1999) Portable X-ray fluorescence spectrometry characterization of a German military site for arsenic contamination in soil. J Field Anal Chem 4:2-17

Publisher's Note Springer Nature remains neutral with regard to jurisdictional claims in published maps and institutional affiliations. 